
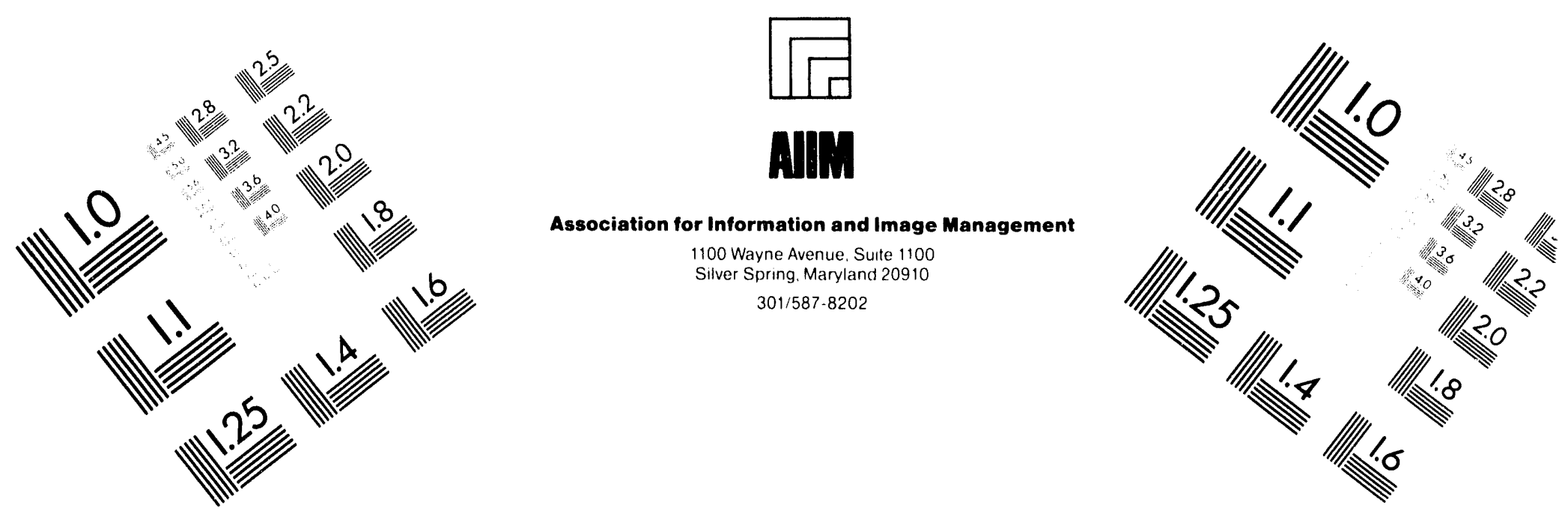

\title{
Centimeter
}

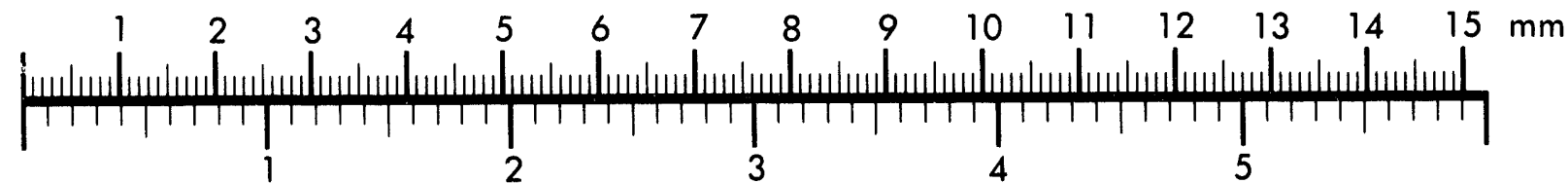

Inches
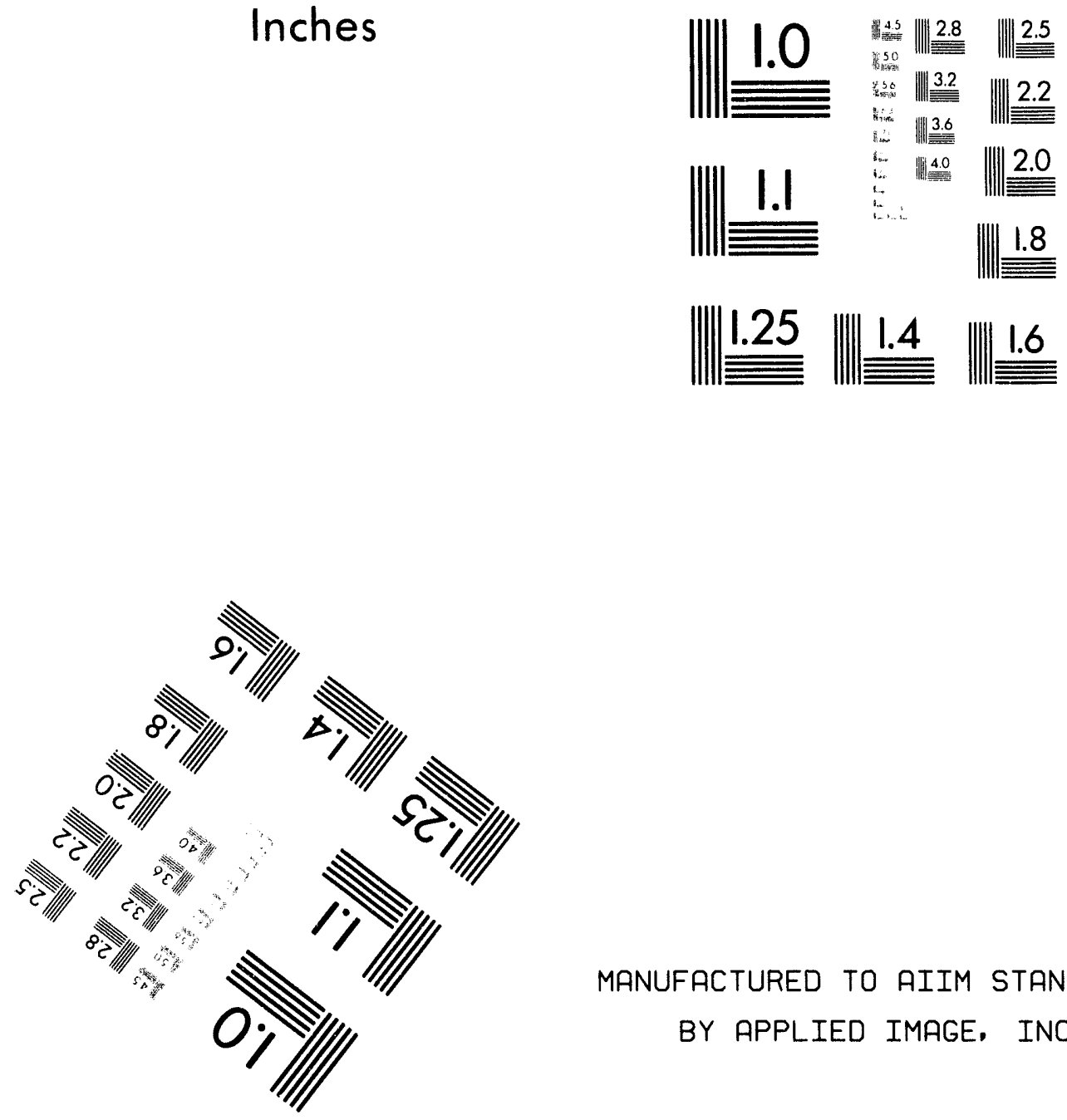

MANUFACTURED TO AIIM STANDARDS

BY APPLIED IMAGE, INC.

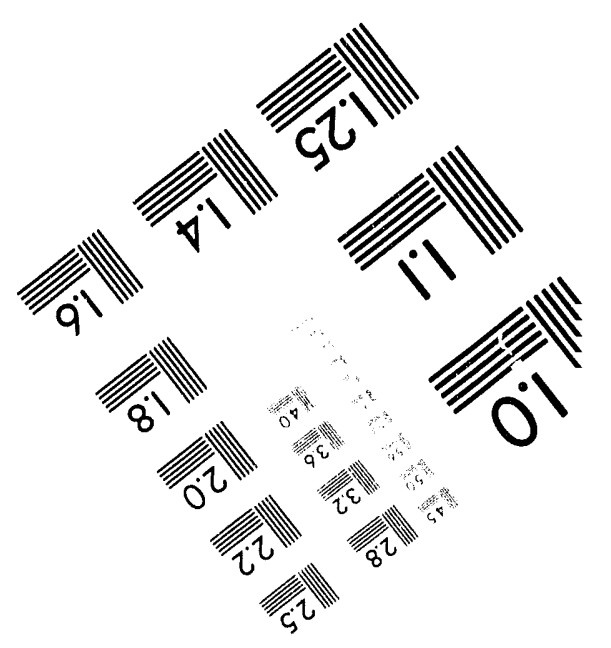


.

.
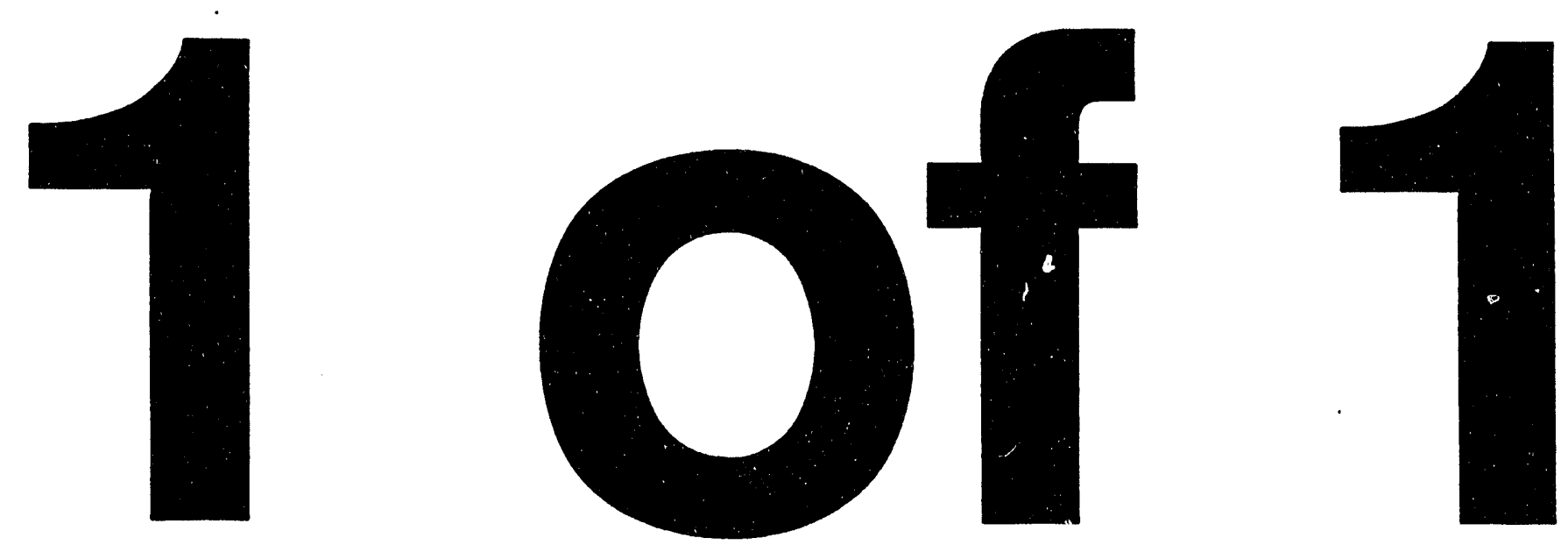
PNL-9455

UC-602

\section{Radionuclide Concentrations in Agricultural Products Near the Hanford Site, 1982 Through 1992}

E. J. Antonio

June 1994

Prepared for

the U.S. Department of Energy

under Contract DE-AC06-76RLO 1830

Pacific Northwest Laboratory

Richland, Washington 99352

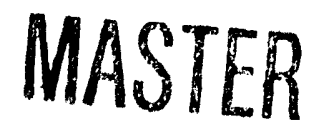

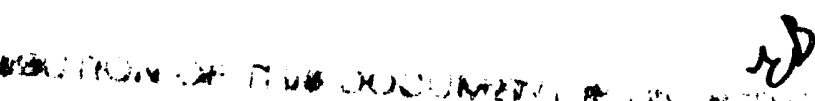




\section{Summary}

The Pacific Northwest Laboratory reviewed monitoring data for agricultural products collected from 1982 through 1992 near the Hanford Site to determine radionuclide concentration trends. While samples were collected and analyzed, and results reported annually in Hanford Site environmental reports, an 11-year data set was reviewed for this report to increase the ability to assess trends and potential Hanford effects. Products reviewed included milk, chicken, eggs, beef, vegetables, fruit, wine, wheat, and alfalfa.

To determine which radionuclides were detected sufficiently often to permit analysis for trends and effects, each radionuclide concentration and its associated uncertainty were ratioed. Radionuclides were considered routinely detectable if more than $50 \%$ of the ratios were between zero and one. Data for these radionuclides were then analyzed statistically, using analyses of variance.

The statistical analyses indicated the following:

- For the most part, there were no measurable effects for Hanford operations.

- Radionuclide concentrations in all products reviewed remained relatively low when compared to concentrations that would result in a 1-mrem effective dose equivalent to an individual.

- Radionuclide concentrations are decreasing in general; however, ${ }^{90} \mathrm{Sr}$ concentrations in all media and ${ }^{129} \mathrm{I}$ in milk increased from 1982 to 1986 , then decreased gradually for the remainder of the review period. The ${ }^{129} \mathrm{I}$ concentrations may be correlated with processing of irradiated reactor fuel at the Plutonium-Uranium Extraction (PUREX) Plant. 


\section{Acknowledgments}

The author would like to thank Rodger Woodruff and Monte Sula for reviewing early versions of the report and providing useful comments, and Ted Poston and Charlie Brandt for technical review of later versions. The author also greatly appreciates the work of Tom Cooper who graphed the data numerous times. 


\section{Contents}

Summary $\ldots \ldots \ldots \ldots \ldots \ldots \ldots \ldots \ldots \ldots \ldots \ldots \ldots \ldots \ldots \ldots \ldots$ iii

Acknowledgments

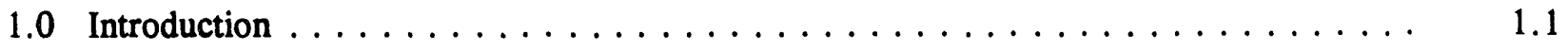

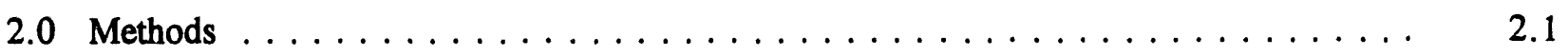

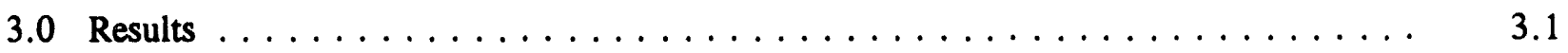

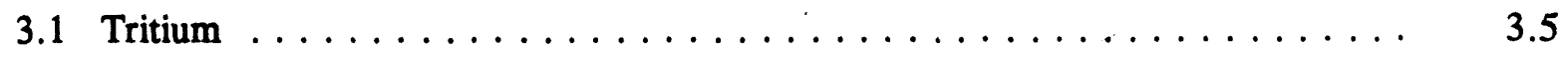

3.2 Strontium $-89 \ldots \ldots \ldots \ldots \ldots \ldots \ldots \ldots \ldots \ldots \ldots \ldots \ldots \ldots$

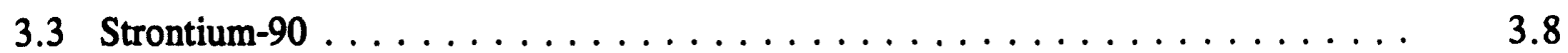

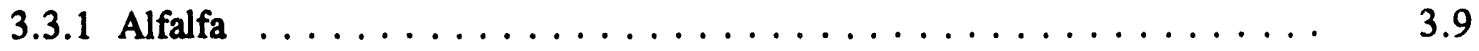

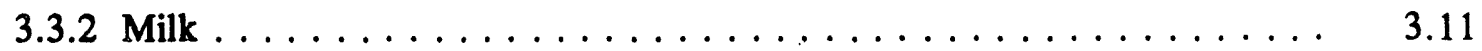

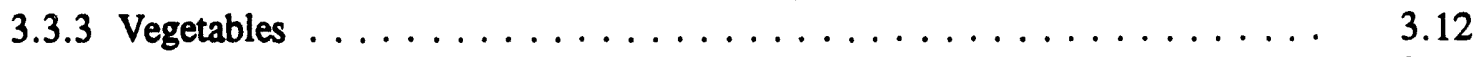

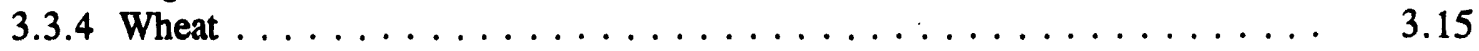

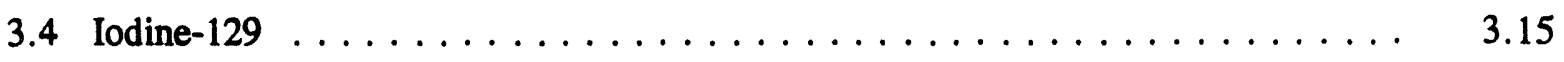

3.5 Iodine-131 $\ldots \ldots \ldots \ldots \ldots \ldots \ldots \ldots \ldots \ldots \ldots \ldots \ldots \ldots$

4.0 Conclusions $\ldots \ldots \ldots \ldots \ldots \ldots \ldots \ldots \ldots \ldots \ldots \ldots \ldots \ldots \ldots \ldots \ldots$

5.0 References $\ldots \ldots \ldots \ldots \ldots \ldots \ldots \ldots \ldots \ldots \ldots \ldots \ldots \ldots \ldots \ldots \ldots$ 


\section{Figures}

1.1 Exposure Pathways to Humans from Hanford Site Effluents $\ldots \ldots \ldots \ldots \ldots$

2.1 Agricultural Product Sampling Locations and Wind Roses Near the Hanford Site,

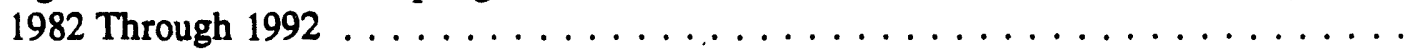

3.1 Estimated Curie Amounts of Tritium Strontium-90, and lodine-129 Released to the Environment from the Hanford Site, 1982 Through $1992 \ldots \ldots \ldots \ldots$. . . . . . . . 3.4

3.2 Interaction Between Upwind/Downwind Locations and Year for ${ }^{3} \mathrm{H}$ in Wine . . . . . 3.6

3.3 Results of Regression Analysis for ${ }^{3} \mathrm{H}$ in Wine from Downwind Locations . . . . . . . $\quad 3.7$

3.4 Results of Regression Analysis for ${ }^{3} \mathrm{H}$ in Wine from Upwind Locations . . . . . . . . . 3.7

3.5 Interactions Between Upwind and Downwind Locations and Year for ${ }^{90} \mathrm{Sr}$ in Alfalfa, 1982 Through $1992 \ldots \ldots \ldots \ldots \ldots$. . . . . . . . . . . . . . . . . . . . 3.10

3.6 Results of Regression Analysis for ${ }^{90} \mathrm{Sr}$ in Alfalfa $\ldots \ldots \ldots \ldots \ldots \ldots$

3.7 Strontium-90 Concentrations ( \pm 2 SEM) in Alfalfa Routinely Collected at Riverview and Richland and All Other Sampling Locations,

3.8 Interactions Between Upwind and Downwind Locations and Year for ${ }^{90} \mathrm{Sr}$ in Milk,

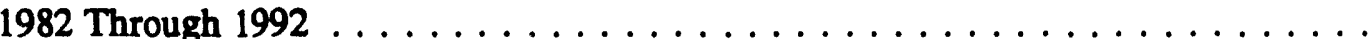

3.9 Results of Regression Analysis for ${ }^{90} \mathrm{Sr}$ in Milk $\ldots \ldots \ldots \ldots \ldots \ldots \ldots$

3.10 Interactions Between Upwind and Downwind Locations and Year for ${ }^{90} \mathrm{Sr}$ in Vegetables,

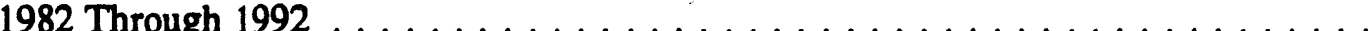

3.11 Results of Regression Analysis for ${ }^{90} \mathrm{Sr}$ in Vegetables $\ldots \ldots \ldots \ldots \ldots \ldots$

3.12 Interactions Between Upwind and Downwind Locations and Year for ${ }^{90} \mathrm{Sr}$ in Wheat,

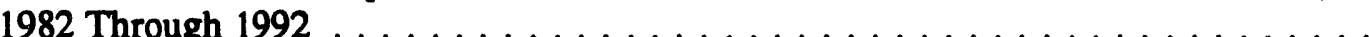

3.13 Results of Regression Analysis for ${ }^{90} \mathrm{Sr}$ in Wheat $\ldots \ldots \ldots \ldots$

3.14 Interactions Between Upwind and Downwind Locations and Year for ${ }^{129} \mathrm{I}$ in Milk,

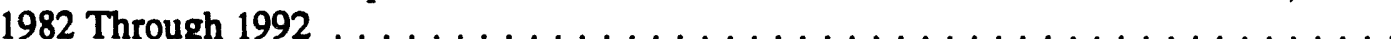

3.15 Results of Regression Analysis for Upwind Locations for ${ }^{129} \mathrm{I}$ in Milk . . . . . . . . . .

3.16 Results of Regression Analysis for Downwind Locations for ${ }^{129} \mathrm{I}$ in Milk . . . . . . . . 
3.17 Iodine-131 Concentrations in Milk, 1982 Through $1992 \ldots \ldots \ldots . \ldots$

4.1 Annual Hanford ${ }^{129}$ I Air Emissions and Annual Average Milk Concentrations,

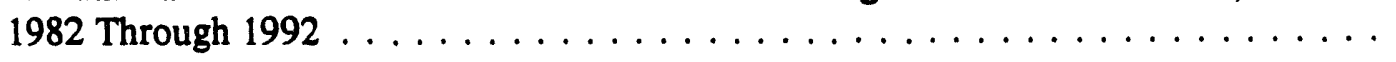

\section{Tables}

1.1 Crop Production Around the Hanford Site, $1990 \ldots \ldots \ldots \ldots \ldots \ldots$

2.1 Minimum Detectable Concentrations for Radiochemical Analysis as Specified in Contracts with Analytical Laboratories, 1982 Through $1992 \ldots \ldots$. . . . . . . . .

2.2 Contractual Minimum Detectable Concentrations for Gamma Spectroscopy,

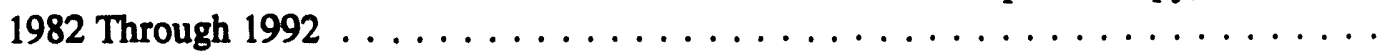

3.1 Agricultural Products Sampled, 1982 Through $1992 \ldots \ldots \ldots \ldots \ldots \ldots$

3.2 Agricultural Product Sampling Areas and Media Sampled,

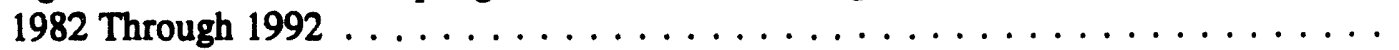

3.3 Typical Yearly Sampling Schedule for Agricultural Products

\subsection{Proportion of Detectable Radionuclide - Media Combinations} During the Review Period . . . . . . . . . . . . . . . . . . .

3.5 Tritium in Wine, 1992 


\subsection{Introduction}

The Hanford Site in southeastern Washington State was established in the 1940s with a mission of producing nuclear materials for national defense. Environmental surveillance in various forms has been performed since the beginning of operations in 1944. The primary goal of environmental surveillance at the Hanford Site is to determine compliance with public exposure limits and applicable environmental quality standards. This goal is accomplished in part by analyzing samples of foodstuffs and other biological media on and around the Hanford Site for contaminants, assessing any Hanford contribution to contaminant levels, and evaluating the results in terms of human doses.

In 1990, the U.S. Department of Energy (DOE) began establishing a new mission for Hanford including:

- management of stored defense wastes and the handling, storage, and disposal of radioactive, mixed, hazardous, or sanitary wastes from current operations

- environmental restoration of approximately 1100 inactive radioactive, mixed, and hazardous waste sites and about 100 surplus facilities

- research and development in energy, health, safety, environmental sciences, molecular sciences, environmental restoration, waste management, and national security

- technology development of new environmental restoration and waste management technologies, including site characterization and assessment methods; waste minimization, treatment, and remediation technology; and education outreach programs (Woodruff et al. 1992).

This change in mission affected Hanford operations, which in turn changed potential impacts of operations. Agricultural products may be exposed to Hanford Site radioactivity via two major pathways: deposition of radioactivity present in the atmosphere and irrigation water removed from the Columbia River downstream of liquid discharges originating on the Site. The significance of atmospheric emissions was recently summarized by Patton and Cooper (1993) for the years 1983 to 1992 . Atmospheric emissions from the Hanford Site have included the radioactive gases ${ }^{85} \mathrm{Kr}$ and ${ }^{41} \mathrm{Ar}$, which do not settle on or accumulate in agricultural products. Other radionuclides released into the atmosphere include tritium $\left({ }^{3} \mathrm{H}\right),{ }^{14} \mathrm{C},{ }^{129} \mathrm{I},{ }^{220} \mathrm{Rn}$, and ${ }^{239,240} \mathrm{Pu}$. Strontium-90 and ${ }^{137} \mathrm{Cs}$ were very minor constituents of atmospheric emissions from the Hanford Site, but contribute significantly to background levels of radioactivity because of their global dissemination from aboveground nuclear weapons testing. Collectively, these two radionuclides are a small percentage $(<1 \%)$ of the total amount of activity released to the atmosphere between 1982 and 1992 . During this time, the primary sources of atmospheric radioactivity on the Hanford Site were:

- N Reactor, which operated into the first week of 1987 
- the Fast Flux Test Facility (FFTF) (1985 to 1991)

- the Plutonium-Uranium Extraction (PUREX) Plant (November 1983 to December 1988, and December 1989 to March 1990)

- the Uranium-Oxide $\left(\mathrm{UO}_{3}\right)$ Finishing Plant (1984 through December 1989)

- Z Plant (1985 through 1987 and 1989).

Emission estimates for this time period do not include fugitive sources.

Nine reactors operated on the banks of the Columbia River for various lengths of time from 1945 to 1987 . These were, from upstream to downstream, B, C, K East and K West, N, DR, D, H, and F. $\mathrm{N}$ Reactor was the last to be shut down (1987). It was a dual-purpose reactor in that it produced plutonium and generated steam to produce electricity. It also differed from the other eight in that it was graphite-moderated and Columbia River water was passed through a heat exchanger and not directly through the reactor core. The other eight reactors used Columbia River water in oncethrough-cooling systems. The water was then returned either directly to the river or after a short thermal cooling period in settling basins. Routine monitoring of the Columbia River started shortly after the start up of the original plutonium production reactors. Historically, radionuclide analytes in Columbia River water have included ${ }^{24} \mathrm{Na},{ }^{32} \mathrm{P},{ }^{51} \mathrm{Cr},{ }^{64} \mathrm{Cu},{ }^{65} \mathrm{Zn},{ }^{76} \mathrm{As},{ }^{89} \mathrm{Sr},{ }^{90} \mathrm{Sr},{ }^{131} \mathrm{I}$, and ${ }^{239} \mathrm{~Np}$ (Denham et al. 1993).

The Columbia River is used as a source of drinking water at communities downstream of the Hanford Site and is a source of irrigation water for crops. Other uses of the river include recreational activities such as fishing, boating, and swimming. A schematic of possible exposure routes to humans is shown in Figure 1.1.

Agriculture is a major factor in the economy of the area surrounding the Hanford Site. Crop production in 1990 is summarized in Table 1.1. Assurance that the regional agricultural products are not contaminated is vital to the public, the region's agribusinesses, and DOE's ability to continue Hanford operations. Periodic sampling, therefore, is essential and should be done in a manner that provides the ability to estimate any contribution from Site operations.

Agricultural products were sampled and analyzed each growing season during the period of this report, and the results have been presented in annual Hanford Site environmental reports (e.g., Woodruff et al. 1991). An objective of this report was to identify long-term trends or significant yearto-year changes in radionuclide concentrations in agricultural products for the past decade. Another objective was to assess the impact of Hanford operations by comparing concentrations in unaffected and potentially affected areas. This report discusses how results of agricultural product surveillance were reviewed (methods) and the trends and effects that were identified (results). Conclusions and references are also provided. 


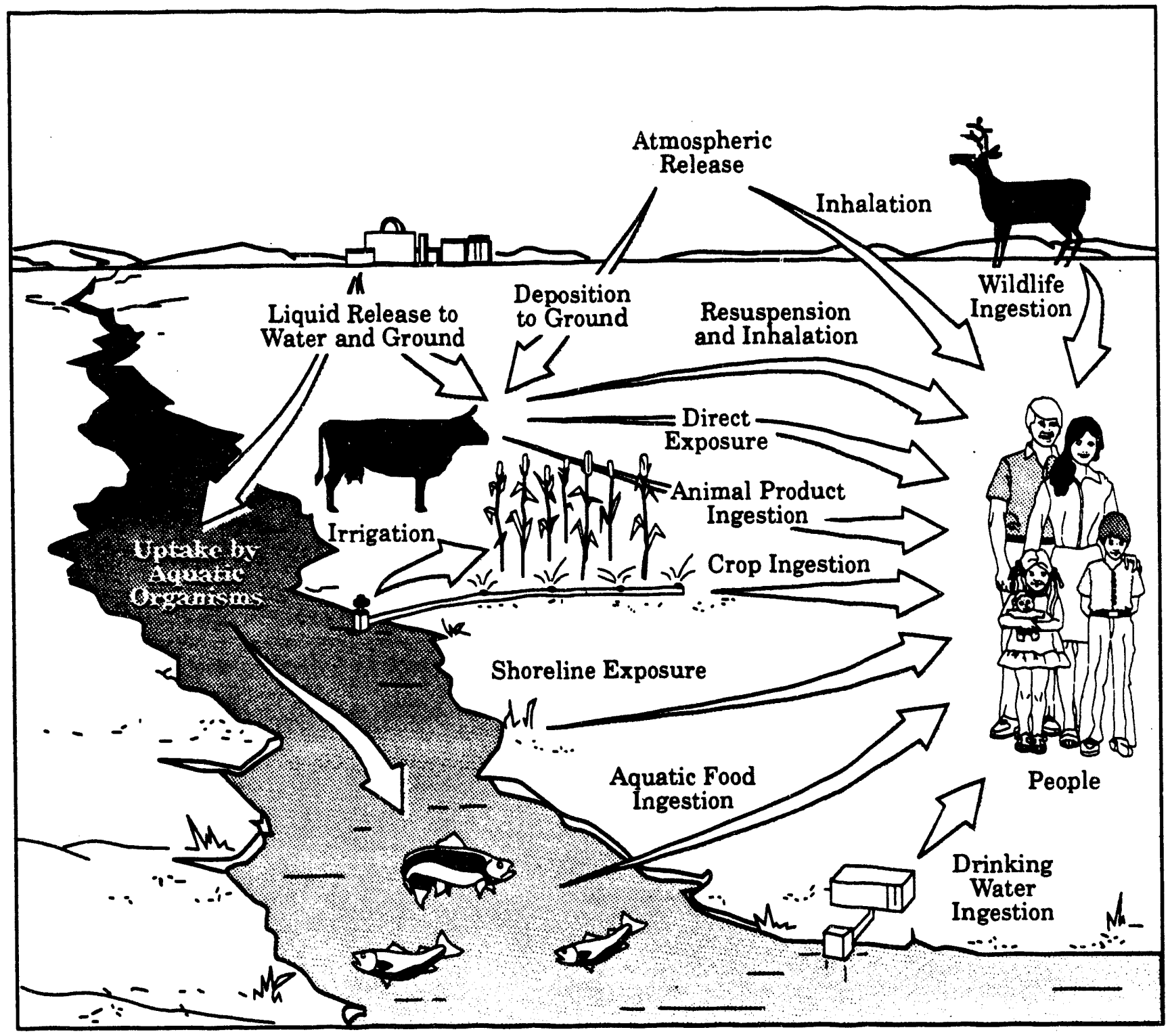

S9203058.131C

Figure 1.1. Exposure Pathways to Humans from Hanford Site Effluents 
Table 1.1. Crop Production Around the Hanford Site, 1990 (Supply System ca. 1991)

\begin{tabular}{|c|c|c|c|c|c|c|}
\hline & $\begin{array}{c}\text { Alfalfa, } \\
\text { ktons }\end{array}$ & $\begin{array}{c}\text { Wheat, } \\
\mathrm{MBu}\end{array}$ & $\begin{array}{l}\text { Corn, } \\
\mathrm{MBu}\end{array}$ & $\begin{array}{c}\text { Apples, } \\
\text { ktons }\end{array}$ & $\begin{array}{l}\text { Hops, } \\
\text { Ktons }\end{array}$ & $\begin{array}{c}\text { Grapes, } \\
\text { ktons }\end{array}$ \\
\hline Franklin County & 388 & 2.9 & 0.9 & 102 & - & 14 \\
\hline Grant County & 304 & 4.4 & 1.4 & 137 & - & - \\
\hline Benton County & 84 & 5.2 & 5.8 & 20 & 0.6 & 14 \\
\hline Adams County & 126 & 2.1 & 0.8 & 18 & - & 0.4 \\
\hline Yakima County & 103 & 1.3 & 0.9 & 329 & 24 & 120 \\
\hline
\end{tabular}




\subsection{Methods}

The Pacific Northwest Laboratory currently manages the Hanford Site Surface Environmental Surveillance Project (SESP) to collect and analyze agricultural product samples. The SESP also maintains a database of past sampling results. This database wis searched for agricultural data from the inclusive dates of January 1, 1982, through December 31, 1992. Locations used for sampling during that time are shown in Figure 2.1. Radionuclide concentrations in milk, chicken, eggs, beef, vegetables, fruit, wine, wheat, and alfalfa were reviewed. The radionuclides routinely detected are reported here. Minimum detectable concentrations (MDC), the lowest concentration that the analytical laboratory can reliably detect, for various radionuclides are presented in Tables 2.1 and 2.2. The only change in MDCs noted between 1982 and 1992 was for plutonium whose MDC decreased from 0.0006 $\mathrm{pCi} / \mathrm{g}$ to $0.0004 \mathrm{pCi} / \mathrm{g}$. (A picocurie, $\mathrm{pCi}$, is a quantity of any radionuclide that decays at the rate of 2.22 radioactive disintegrations per minute. One $\mathrm{aCi}$ is approximately equal to one radioactive disintegration per year.)

To determine which radionuclides were detected sufficiently often to permit analysis for trends and effects, each radionuclide concentration and its associated counting error or uncertainty were ratioed. (The error term was the numerator and the concentration was the denominator.) If the ratio was negative or greater than one, the result was either negative or the associated error term was larger than the calculated concentration. (Although negative radionuclide concentrations in a medium are impossible, it is possible for an analytical test to yield a negative result when the radionuclide concentration is zero or well below the MDC.) In such cases, the radionuclide was considered nondetectable. Radionuclides were considered detectable if the ratio was between zero and one. Radionuclides were considered routinely detectable if more than $50 \%$ of the ratios were between zero and one.

When a radionuclide was determined to be routinely detectable in an agricultural medium, the following procedure was conducted:

1. The distribution of the data was analyzed for normality. When the Jata were not normally distributed, they were logarithmically transformed in an attempt to achieve normality. This allowed the use of normal statistics on the data.

2. Analyses of variance (ANOVA) were performed on log-transformed data grouped by upwind/ downwind location designation and by year. The upwind/downwind analysis was used to determine whether a Hanford effect was evident. The year analysis was used to determine whether a significant year-to-year change in the data had occurred. (This analysis carries less statistical weight because of unbalanced yearly sampling, i.e., different numbers of samples taken each year.) The interaction between upwind/downwind and year was also studied to interpret simple effects (i.e., the differences between radionuclide concentrations at upwind and downwind locations and how concentrations changed from year to year). A P-value for each ANOVA of less than 0.1 was considered significant. 


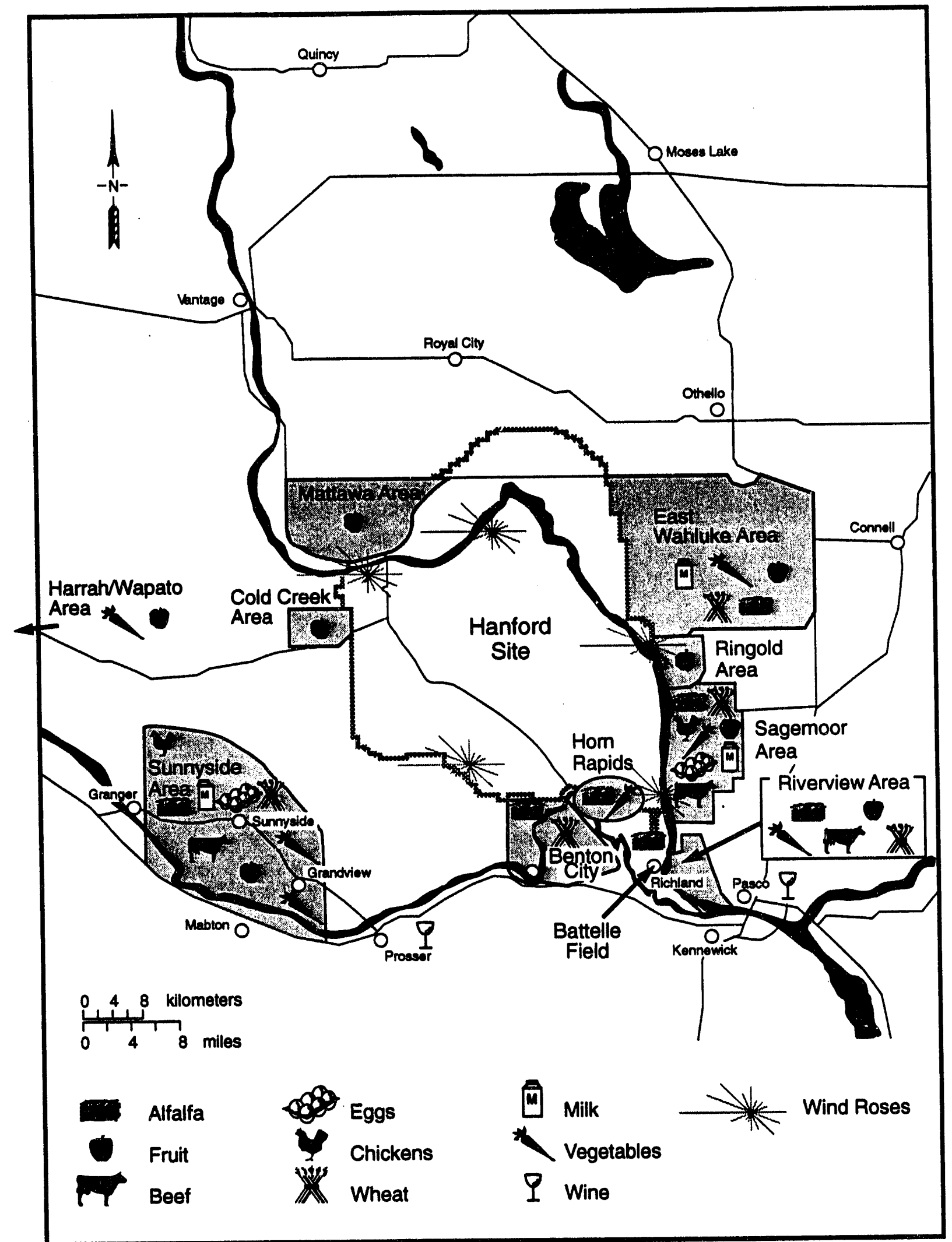

S9401058.1

Figure 2.1. Agricultural Product Sampling Locations and Wind Roses Near the Hanford Site, 1982 Through 1992. (Not all locations were used each year.) 
Table 2.1. Minimum Detectable Concentrations for Radiochemical Analysis as Specified in Contracts with Analytical Laboratories, 1982 Through 1992

\begin{tabular}{|c|c|c|}
\hline Analysis Type & Sample Type & Required MDC \\
\hline \multirow[t]{4}{*}{${ }^{3} \mathrm{H}$} & Fruit & $300 \mathrm{pCi} / \mathrm{L}$ \\
\hline & Milk & $300 \mathrm{pCi} / \mathrm{L}$ \\
\hline & Vegetables & $300 \mathrm{pCi} / \mathrm{L}$ \\
\hline & Wine & $300 \mathrm{pCi} / \mathrm{L}$ \\
\hline${ }^{89} \mathrm{Sr}$ & Milk & $5 \mathrm{pCi} / \mathrm{L}$ \\
\hline \multirow[t]{5}{*}{${ }^{90} \mathrm{Sr}$} & Fruit & $0.005 \mathrm{pCi} / \mathrm{g}$ \\
\hline & Meat & $0.005 \mathrm{pCi} / \mathrm{g}$ \\
\hline & Milk & $2 \mathrm{pCi} / \mathrm{L}$ \\
\hline & Vegetables & $0.005 \mathrm{pCi} / \mathrm{g}$ \\
\hline & Wheat \& Alfalfa & $0.005 \mathrm{pCi} / \mathrm{g}$ \\
\hline \multirow[t]{4}{*}{129} & Fruit & $1 \mathrm{pCi} / \mathrm{g}$ \\
\hline & Meat & $1 \mathrm{pCi} / \mathrm{g}$ \\
\hline & Milk $^{(a)}$ & $0.000006 \mathrm{aCi} / \mathrm{L}$ \\
\hline & Vegetables & $1 \mathrm{pCi} / \mathrm{g}$ \\
\hline${ }^{131} \mathbf{I}$ & Milk & $0.5 \mathrm{pCi} / \mathrm{L}$ \\
\hline \multirow[t]{4}{*}{${ }^{239,240} \mathrm{Pu}$} & Fruit & $0.0004 \mathrm{pCi} / \mathrm{g}$ \\
\hline & Meat & $0.0004 \mathrm{pCi} / \mathrm{g}$ \\
\hline & Vegetables & $0.0004 \mathrm{pCi} / \mathrm{g}$ \\
\hline & Wheat \& Alfalfa & $0.0004 \mathrm{pCi} / \mathrm{g}$ \\
\hline
\end{tabular}

(a) Mass spectral analysis detection limit of 7000 atoms converted to activity of $0.00024 \mathrm{aCi}$.

3. Regardless of any difference identified, a series of regressions, both linear and quadratic, was performed on the separate data sets to determine how the concentration of a radionuclide changed with time. The line of best fit will be discussed.

Some concentrations of some radionuclides in some media were 'not routinely detectable' but had consistent anomalies of interest. Although no ANOVAs or regression analyses were performed on these data, they were plotted to show the anomaly. 
Table 2.2. Contractual Minimum Detectable Concentrations for Gamma Spectroscopy, 1982 Through 1992

\begin{tabular}{|c|c|c|c|c|}
\hline Radionuclide & $\begin{array}{c}\text { Meat, Chicken \& } \\
\text { Eggs, Wheat, } \\
\text { Alfalfa; } \\
\text { pCi/g }\end{array}$ & $\begin{array}{l}\text { Milk, } \\
\text { pCi/L }\end{array}$ & $\begin{array}{l}\text { Produce, } \\
\text { Vegetables, } \\
\text { \& Fruit; } \\
\text { pCi/g }\end{array}$ & $\begin{array}{l}\text { Wine, } \\
\mathrm{pCi} / \mathrm{L}\end{array}$ \\
\hline${ }^{7} \mathrm{Be}$ & 0.08 & 61 & 0.04 & 46 \\
\hline${ }^{22} \mathrm{Na}$ & 0.02 & 8 & 0.01 & 6 \\
\hline${ }^{24} \mathrm{Na}$ & 0.02 & 11 & 0.01 & 8 \\
\hline${ }^{40} \mathrm{~K}$ & 0.02 & 144 & 0.10 & 105 \\
\hline${ }^{54} \mathbf{M n}$ & 0.02 & 8 & 0.01 & 6 \\
\hline${ }^{58} \mathrm{Co}$ & 0.02 & 8 & 0.01 & 6 \\
\hline${ }^{60} \mathrm{Co}$ & 0.01 & 9 & 0.01 & 7 \\
\hline${ }^{59} \mathrm{Fe}$ & 0.02 & 14 & 0.01 & 10 \\
\hline${ }^{65} \mathrm{Zn}$ & 0.02 & 17 & 0.01 & 13 \\
\hline${ }^{95} \mathrm{Zr} / \mathrm{Nb}$ & 0.02 & 14 & 0.01 & 10 \\
\hline${ }^{90} \mathrm{Mo}$ & 0.08 & 55 & 0.04 & 41 \\
\hline${ }^{103} \mathrm{Ru}$ & 0.02 & 8 & 0.01 & 6 \\
\hline${ }^{106} \mathrm{Ru}$ & 0.10 & 69 & 0.05 & 52 \\
\hline${ }^{125} \mathrm{Sb}$ & 0.03 & 19 & 0.02 & 14 \\
\hline${ }^{131} I$ & 0.02 & 0.05 & 0.01 & 6 \\
\hline${ }^{134} \mathrm{Cs}$ & 0.02 & 9 & 0.01 & 7 \\
\hline${ }^{137} \mathrm{Cs}$ & 0.02 & 8 & 0.02 & 6 \\
\hline${ }^{140} \mathrm{Ba} / \mathrm{La}$ & 0.03 & 19 & 0.02 & 14 \\
\hline${ }^{141} \mathrm{Ce}$ & 0.02 & 8 & 0.01 & 6 \\
\hline${ }^{144} \mathrm{Ce} / \mathrm{Pr}$ & 0.11 & 74 & 0.06 & 56 \\
\hline${ }^{152} \mathrm{Eu}$ & 0.06 & 45 & 0.03 & 34 \\
\hline${ }^{154} \mathrm{Eu}$ & 0.03 & 22 & 0.02 & 16 \\
\hline${ }^{155} \mathrm{Eu}$ & 0.03 & 19 & 0.02 & 14 \\
\hline
\end{tabular}

When data sets contained anomalous or far-outlying data points that appeared to greatly differ from the mean, or median, a decision was made to reject or retain the data point. The decision was based on the $Q$ test, where the difference between the suspect outlier and its nearest neighbor is divided by the spread of the entire data set. The resulting ratio is then compared with rejection values that are critical for a particular degree of confidence (Skoog and West 1980). 


\subsection{Results}

Between 1982 and 1992, agricultural samples were collected from locations shown in Figure 2.1. Not all media were collected from the same locations each year (see Tables 3.1 and 3.2). Agricultural product sampling has changed over the years to reflect changes in Hanford operations, observed changes in contaminant concentrations in specific media, and changes in the local production of some agricultural products. A typical yearly sampling schedule for agricultural products is presented in Table 3.3.

The following sections report specific radionuclide concentrations in agricultural products where concentrations were routinely detectable. Radionuclide concentrations in units of $\mathrm{pCi} / \mathrm{g}$ in vegetation are on a dry-weight basis, and those in beef, eggs, and poultry are on a wet-weight basis. Concentrations of ${ }^{3} \mathrm{H}$ are expressed in $\mathrm{pCi} / \mathrm{L}$ of milk or wine. To aid the reader in data interpretation, the nonlog-transformed data are plotted on log-scaled graphs.

Table 3.4 shows the proportion of detectable gamma-emitting radionuclide concentrations in each of the nine agricultural products relative to the number of gamma spectral measurements. Potassium-40, a naturally occurring radionuclide (NCRP 1976, 1978) comprising $0.0118 \%$ of natural K (Friedlander et al. 1964; USDHEW 1970), was detected in all samples reviewed for this report. Also, for some of the gamma-emitting radionuclides, results were occasionally not reported if the isotope was not identified as being present in the sample. The number of nongamma analyses,

Table 3.1. Agricultural Products Sampled, 1982 Through 1992

\begin{tabular}{|c|c|c|c|c|c|c|c|c|c|c|c|}
\hline \multirow[b]{2}{*}{ Sample Type } & \multicolumn{11}{|c|}{ Year } \\
\hline & $\underline{1982}$ & $\underline{1983}$ & $\underline{1984}$ & $\underline{1985}$ & $\underline{1986}$ & $\underline{1987}$ & $\underline{1988}$ & $\underline{1989}$ & 1990 & $\underline{1991}$ & $\underline{1992}$ \\
\hline Alfalfa & $\mathbf{X}$ & $\mathbf{X}$ & $\mathbf{X}$ & $\mathbf{X}$ & $\mathbf{X}$ & $\mathbf{X}$ & $\mathbf{X}$ & $\mathbf{X}$ & $\mathbf{X}$ & $\mathbf{X}$ & $\mathbf{X}$ \\
\hline Beef & $\mathbf{X}$ & & $\mathbf{X}$ & $\mathbf{X}$ & $\mathbf{X}$ & $\mathbf{X}$ & $\mathbf{X}$ & $\mathbf{X}$ & $\mathbf{X}$ & $\mathbf{X}$ & $\mathbf{X}$ \\
\hline Chicken & $\mathbf{X}$ & $\mathbf{X}$ & $\mathbf{X}$ & $\mathbf{X}$ & $\mathbf{X}$ & $\mathbf{X}$ & $\mathbf{X}$ & $\mathbf{X}$ & $\mathbf{X}$ & $\mathbf{X}$ & $\mathbf{X}$ \\
\hline Eggs & $\mathbf{X}$ & $\mathbf{X}$ & $\mathbf{X}$ & $x$ & $\mathbf{X}$ & $\mathbf{x}$ & $\mathbf{X}$ & $\mathbf{X}$ & $\mathbf{X}$ & $\mathbf{X}$ & $\mathbf{X}$ \\
\hline Fruit & $\mathbf{x}$ & $\mathbf{x}$ & $\mathbf{X}$ & $\mathbf{x}$ & $\mathbf{x}$ & $\mathbf{x}$ & $\mathbf{x}$ & $\mathbf{X}$ & $\mathbf{x}$ & $\mathbf{X}$ & $\mathbf{x}$ \\
\hline Milk & $\mathbf{x}$ & $\mathbf{x}$ & $\mathbf{x}$ & $\mathbf{x}$ & $\mathbf{x}$ & $\mathbf{X}$ & $\mathbf{x}$ & $\mathbf{X}$ & $\mathbf{x}$ & $\mathbf{X}$ & $\mathbf{X}$ \\
\hline Vegetables & $\mathbf{X}$ & $\mathbf{X}$ & $\mathbf{X}$ & $\mathbf{X}$ & $\mathbf{X}$ & $\mathbf{X}$ & $\mathbf{X}$ & $\mathbf{X}$ & $\mathbf{X}$ & $\mathbf{X}$ & $\mathbf{X}$ \\
\hline Wheat & $\mathbf{X}$ & $\mathbf{x}$ & $\mathbf{X}$ & $\mathbf{x}$ & $\mathbf{x}$ & $\mathbf{X}$ & $\mathbf{X}$ & $\mathbf{x}$ & $\mathbf{x}$ & $\mathbf{X}$ & $\mathbf{X}$ \\
\hline Wine & & & & & & $\mathbf{X}$ & $\mathbf{X}$ & $\mathbf{X}$ & $\mathbf{X}$ & $\mathbf{X}$ & $\mathbf{X}$ \\
\hline
\end{tabular}


Table 3.2. Agricultural Product Sampling Areas and Media Sampled, 1982 Through 1992

Media

Location

Benton City

Columbia Basin

Horn Rapids

Moses Lake

North of Richland

Prosser

Riverview

Sagemoor

Sunnyside

Wahluke

Yakima Valley

\begin{tabular}{|c|c|c|c|c|c|c|c|c|}
\hline$\frac{\text { Alfalfa }}{X}$ & Beef & Chicken & Eggs & 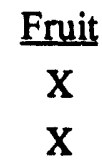 & $\frac{\text { Milk }}{\mathrm{X}}$ & $\frac{\text { Vegetables }}{\mathbf{X}}$ & Wheat & $\begin{array}{c}\text { Wine } \\
\mathrm{X}\end{array}$ \\
\hline $\mathbf{X}$ & $\mathbf{X}$ & & & & & & & \\
\hline $\mathbf{X}$ & & & & $\mathbf{X}$ & $\mathbf{X}$ & $\mathbf{X}$ & & \\
\hline $\mathbf{X}$ & & & & & & & & \\
\hline & & & & & & $\mathbf{X}$ & & \\
\hline $\mathbf{X}$ & $\mathbf{X}$ & & & $\mathbf{X}$ & $\mathbf{X}$ & $\mathbf{X}$ & $\mathbf{X}$ & \\
\hline $\mathbf{X}$ & $\mathbf{X}$ & $\mathbf{X}$ & $\mathbf{X}$ & $\mathbf{X}$ & $\mathbf{X}$ & $\mathbf{X}$ & $\mathbf{X}$ & \\
\hline $\mathbf{X}$ & $\mathbf{X}$ & $\mathbf{X}$ & $\mathrm{X}$ & $\mathbf{X}$ & $\mathbf{X}$ & $\mathbf{X}$ & $\mathbf{X}$ & \\
\hline $\mathbf{X}$ & & & & $\mathrm{X}$ & $\mathbf{X}$ & $\mathbf{X}$ & & \\
\hline
\end{tabular}

Table 3.3. Typical Yearly Sampling Schedule for Agricultural Products

\begin{tabular}{lllc}
\multicolumn{1}{c}{ Sample Type } & \multicolumn{1}{c}{ Frequency } & No. of Samples \\
\cline { 1 - 1 } Alfalfa & & Biannually - Annually & 10 \\
Beef & & Annually & 3 \\
Chicken & & Semiannually & 4 \\
Eggs & & Semiannually & 4 \\
Fruit & Biannually - Annually & 21 \\
Milk & & Biweekly - Semiannually & 56 \\
Vegetables & & Biannually - Annually & 13 \\
Wheat & & Biannually - Annually & 8 \\
Wine & Annually & 4
\end{tabular}

e.g. ${ }^{3} \mathrm{H},{ }^{90} \mathrm{Sr}$, and $\mathrm{Pu}$ isotopes, were not always identical to the number of gamma spectral analyses, because different analyses were requested. The frequency of detection of those isotopes requiring radiochemical separation or purification is based on the number of specific analyses performed. Routinely detectable radionuclides/media of interest from Table 3.4 are ${ }^{3} \mathrm{H}$ in wine; ${ }^{89} \mathrm{Sr}$ in alfalfa; ${ }^{90} \mathrm{Sr}$ in alfalfa, milk, vegetables and wheat; and ${ }^{129} \mathrm{I}$ in milk. Estimated curie amounts of ${ }^{3} \mathrm{H},{ }^{90} \mathrm{Sr}$, and ${ }^{129} \mathrm{I}$ released to the environment are shown in Figure 3.1. 
Table 3.4. Proportion of Detectable Radionuclide - Media Combinations During the Review Period ${ }^{(\mathbf{a})}$

\begin{tabular}{|c|c|c|c|c|c|c|c|c|c|}
\hline Radionuclide & Alfalfa & Beef & Chicken & Eggs & Fruit & Milk & Vegetables & Wheat & Wine \\
\hline${ }^{\mathbf{3}} \mathbf{H}$ & - & - & - & - & 0.43 & 0.42 & -- & -- & $\underline{0.86}$ \\
\hline${ }^{7} \mathrm{Be}$ & 0.37 & - & - & - & 0.02 & 0.01 & 0.07 & 0.01 & $\overline{0.01}$ \\
\hline${ }^{40} \mathrm{~K}$ & 1.00 & 1.00 & 1.00 & 1.00 & 1.00 & 1.09 & 1.00 & 1.00 & 1.00 \\
\hline${ }^{58} \mathrm{Co}$ & 0.01 & - & - & -- & 0.01 & - & - & 0.01 & - \\
\hline${ }^{60} \mathrm{Co}$ & 0.15 & 0.03 & 0.19 & 0.10 & 0.10 & 0.13 & 0.15 & 0.12 & 0.04 \\
\hline${ }^{65} \mathrm{Zn}$ & 0.04 & 0.13 & 0.12 & 0.02 & 0.08 & 0.08 & 0.05 & 0.05 & 0.03 \\
\hline${ }^{89} \mathrm{Sr}$ & 0.61 & - & 0.33 & 0.17 & 0.33 & 0.21 & 0.42 & 0.24 & - \\
\hline${ }^{90} \mathrm{Sr}$ & 1.00 & 0.27 & 0.33 & 0.48 & 0.41 & 0.94 & 0.88 & $\underline{0.89}$ & -- \\
\hline${ }^{95} \mathrm{ZrNb}$ & 0.03 & 0.06 & -- & - & 0.01 & $\overline{0.01}$ & $\overline{0.01}$ & $\overline{0.04}$ & 0.03 \\
\hline${ }^{103} \mathbf{R u}$ & 0.02 & - & - & - & - & - & - & - & - \\
\hline${ }^{106} \mathrm{Ru}$ & 0.04 & 0.09 & - & 0.02 & 0.02 & - & 0.03 & 0.02 & 0.03 \\
\hline${ }^{125} \mathrm{Sb}$ & 0.02 & - & - & 0.02 & - & 0.01 & - & - & - \\
\hline${ }^{129} \mathrm{I}$ & - & - & - & - & - & 0.99 & - & - & - \\
\hline${ }^{131} \mathrm{I}$ & 0.02 & - & - & - & - & $\overline{0.05}$ & - & - & - \\
\hline${ }^{134} \mathrm{Cs}$ & 0.05 & 0.09 & - & - & 0.03 & 0.02 & 0.02 & 0.06 & 0.01 \\
\hline${ }^{137} \mathrm{Cs}$ & 0.23 & 0.31 & 0.10 & 0.15 & 0.09 & 0.18 & 0.21 & 0.18 & 0.05 \\
\hline${ }^{144} \mathrm{CePr}$ & - & - & - & - & - & - & 0.01 & 0.01 & - \\
\hline${ }^{154} \mathrm{Eu}$ & 0.06 & - & - & 0.02 & 0.01 & 0.01 & - & 0.08 & 0.03 \\
\hline${ }^{155} \mathrm{Eu}$ & 0.03 & - & - & - & - & - & - & 0.01 & - \\
\hline${ }^{212} \mathrm{~Pb}$ & 0.08 & - & - & -- & - & - & - & 0.02 & 0.01 \\
\hline${ }^{214} \mathrm{~Pb}$ & 0.02 & - & - & -- & - & - & - & - & - \\
\hline${ }^{224} \mathrm{Ra}$ & 0.03 & - & - & - & - & - & - & - & 0.01 \\
\hline${ }^{226} \mathrm{Ra}$ & 0.02 & - & - & - & - & - & - & - & - \\
\hline${ }^{232} \mathrm{Th}$ & 0.01 & - & - & - & - & - & - & - & -- \\
\hline${ }^{238} \mathrm{Pu}$ & - & -- & - & -- & - & - & - & 0.01 & - \\
\hline${ }^{239,240} \mathrm{Pu}$ & - & - & -- & - & - & - & - & -- & - \\
\hline
\end{tabular}

(a) Underlined numbers indicate combinations that are discussed in this report. 


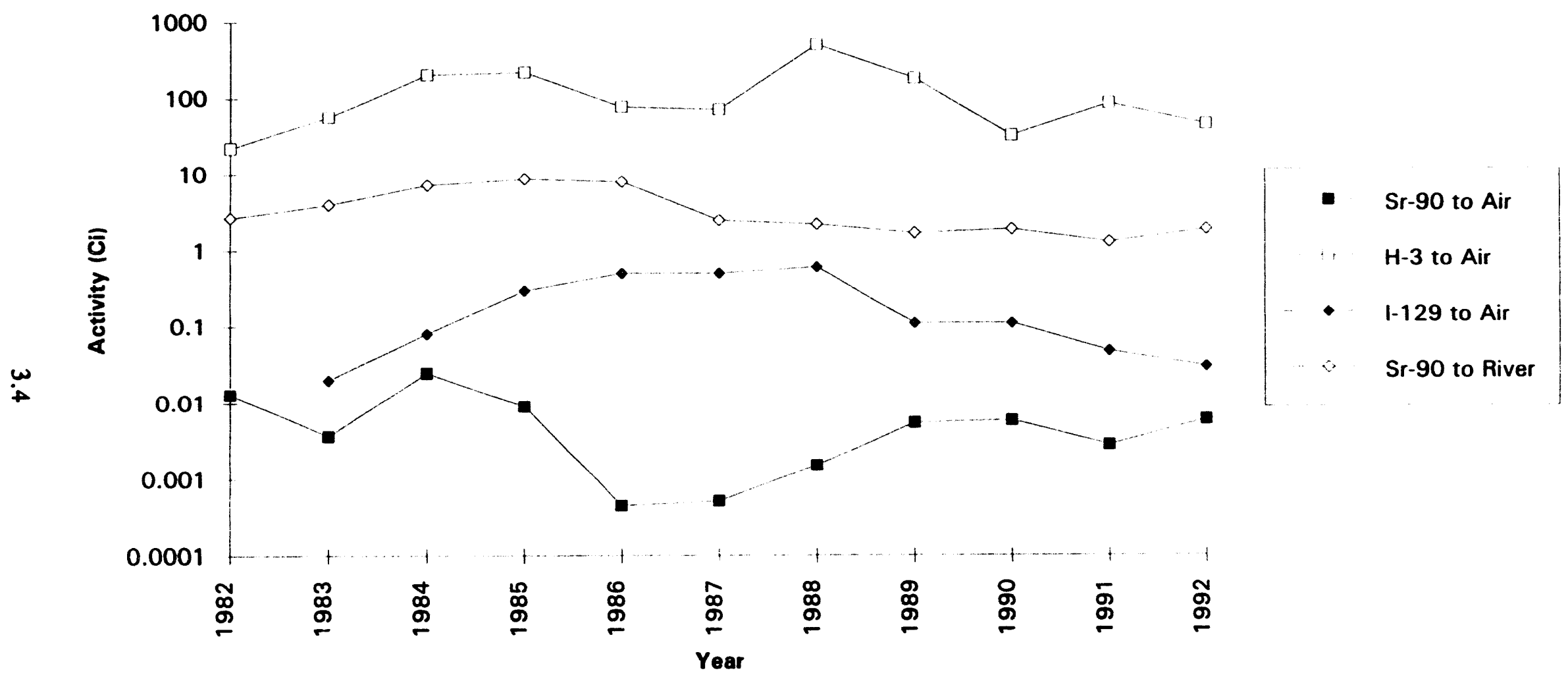

Figure 3.1. Estimated Curie Amounts of Tritium, Strontium-90, and lodine-129 Released to the Environment from the Hanford Site, 1982 Through 1992 


\subsection{Tritium}

Tritium is the radioactive isotope of hydrogen, with a half-life of roughly 12.2 years (USDHEW 1970). Tritium is released to the environment as tritiated water vapor, ${ }^{3} \mathrm{HOH}$, and tritium-hydrogen gas $\left({ }^{3} \mathrm{HH}\right)$ (Till and Meyer 1983). Long-term exposure to ${ }^{3} \mathrm{H}$ results in significant incorporation of ${ }^{3} \mathrm{H}$ into body tissues, in addition to mixing with body water. This low-energy beta emitter (maximum energy $18.6 \mathrm{keV}$ ) is detected by liquid scintillation counting of distillates from the agricultural products. It was routinely reported as detected in wine at very low concentrations.

Red and white wines have been collected and analyzed from the Columbia Basin and the Yakima Valley wineries since 1987; therefore, only 6 years of data are reported here. Although wine was collected in one year, the grapes were grown in the previous year (e.g., wine sampled in 1988 was made from grapes grown in 1987). The Yakima Valley red wines sampled in 1987 were excluded from the statistical analysis because the grapes were grown in 1985 and there were no corresponding Columbia Basin red wines for comparison. The Yakima Valley samples serve as control samples (considered to be unaffected by Hanford releases) and are intended to be used for establishing background concentrations of radionuclides in this media.

Tritium concentrations in wine types (red and white) from the same sampling area were compared, and no difference was found. Further comparisons grouped white and red wine together for each location. The ANOVAs performed on the log-transformed data indicated that samples from the upwind locations were significantly different from those of the downwind locations, P-value $=0.008$; the data across years also showed significant differences, P-value $<0.0001$; and the interaction between the upwind/downwind locations designations and year was significant, $P$-value $=0.0211$. These significant differences indicate that the yearly trends differed between upwind and downwind locations. The upwind/downwind-by-year interaction is shown in Figure 3.2.

The regression analysis for the Columbia Basin (downwind) wines (Figure 3.3) suggests that ${ }^{3} \mathrm{H}$ concentrations increased during the period of 1987 through 1991. The equation of the regression line of log transformed data was:

$$
Y=-191.568+4.267 * X-0.023 * X^{2} ; R^{2}=0.286 \text { and } P=0.0046
$$

The regression analysis for the Yakima Valley (upwind) wines (Figure 3.4) also indicates ${ }^{3} \mathrm{H}$ concentrations in wine increased during the review period. The equation of the regression line of log transformed data was:

$$
Y=-578.465+12.789 * X-0.07 * X^{2} ; R^{2}=0.412 \text { and } P=0.0008
$$

These conclusions are plausible because ${ }^{3} \mathrm{H}$ releases from the Site fluctuated (see Figure 3.1) over this time period with a maximum annual release of $500 \mathrm{Ci}$ in 1988 (Patton and Cooper 1993). One complicating factor is the ch.nge of analytical laboratories in 1990. Following this change, the new 
analytical laboratory had difficulty meeting the minimum detectable concentration goals for ${ }^{3} \mathrm{H}$ in wine, and analyses of other media have strongly suggested periodic laboratory cross contamination in lowlevel ${ }^{3} \mathrm{H}$ analyses (see Section 4.4 in Woodruff et al. 1992). Cross contamination in the laboratory would bias results high.

Another indication of this bias is provided by comparing results of analyses with those from another laboratory. In 1990 to 1992, the Washington State Department of Health co-sampled wine with the SESP. As an example, both sets of results for 1992 differ greatly (Table 3.5). Although there is no established standard for ${ }^{3} \mathrm{H}$ in wine, the standard for ${ }^{3} \mathrm{H}$ in drinking water is $20,000 \mathrm{pCi} / \mathrm{L}$. The concentration of ${ }^{3} \mathrm{H}$ in wine that would nominally yield a 1 mrem effective dose equivalent to the public is approximately $200,000 \mathrm{pCi} / \mathrm{L}$. This concentration would produce a radiological dose of $1 \mathrm{mrem}$ if that concentration of ${ }^{3} \mathrm{H}$ in wine was consumed at the rate of $70 \mathrm{~L} / \mathrm{yr}$ for one year.

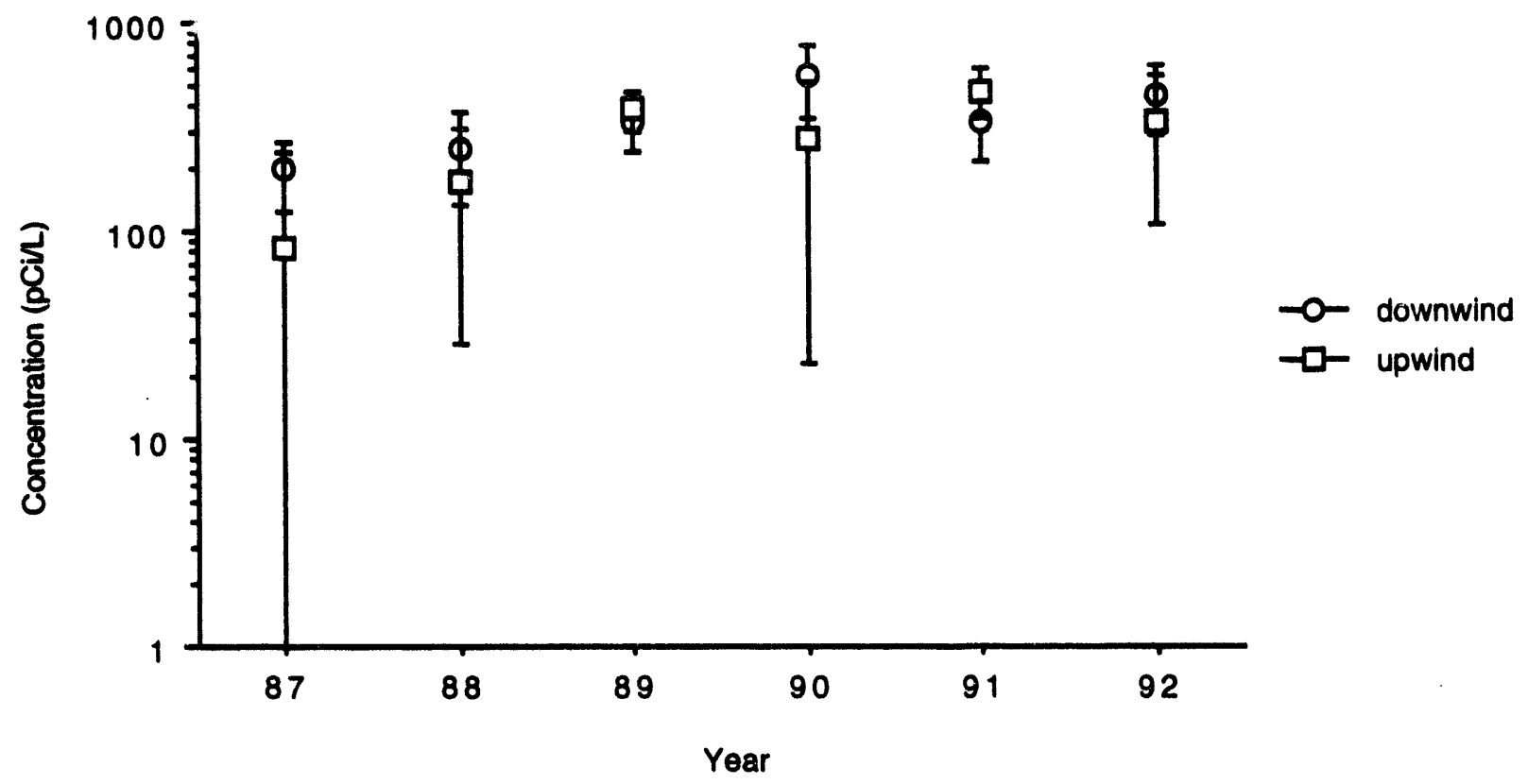

Figure 3.2. Interaction Between Upwind/Downwind Locations and Year for ${ }^{3} \mathrm{H}$ in Wine. Error bars indicate \pm 2 standard errors. 


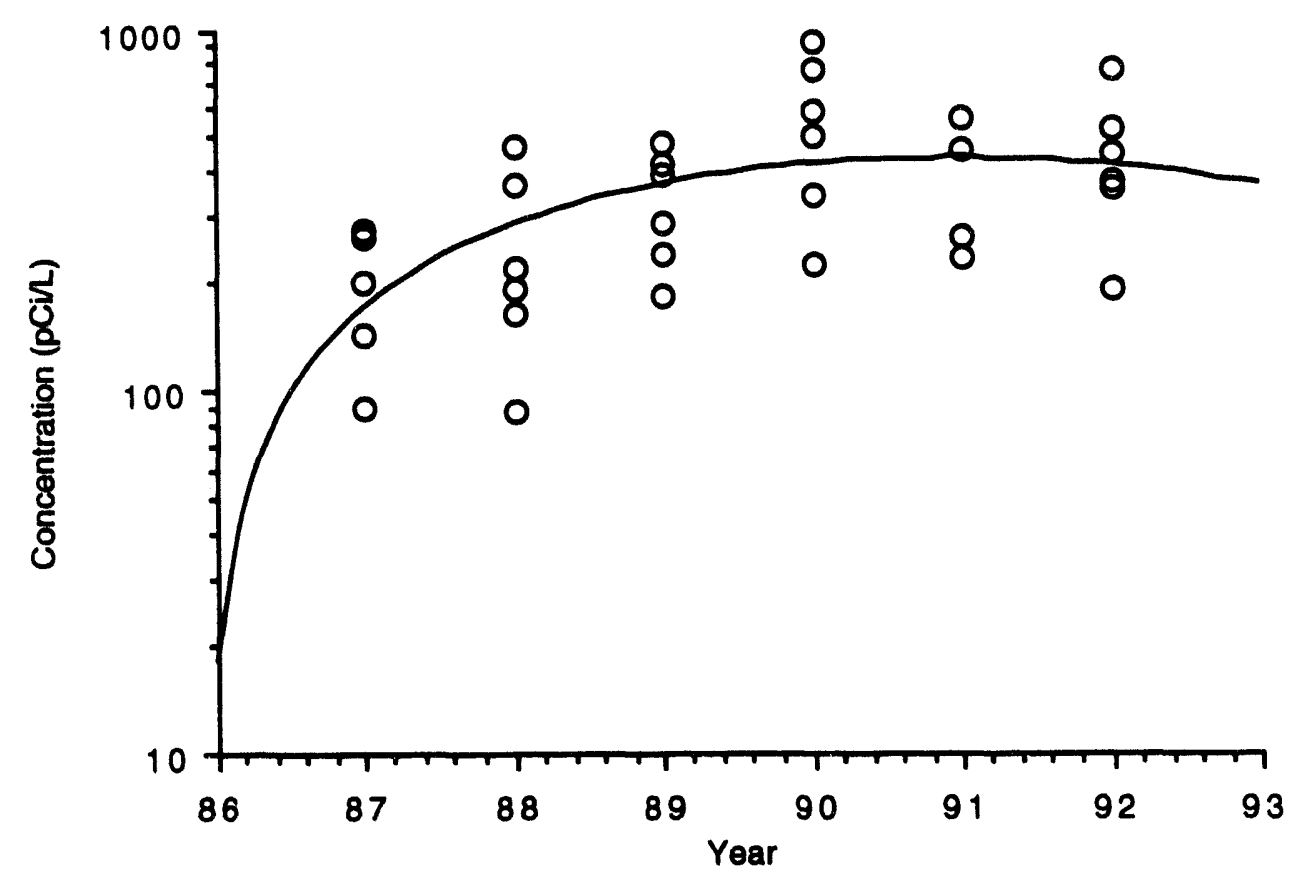

Figure 3.3. Results of Regression Analysis for ${ }^{3} \mathrm{H}$ in Wine from Downwind Locations

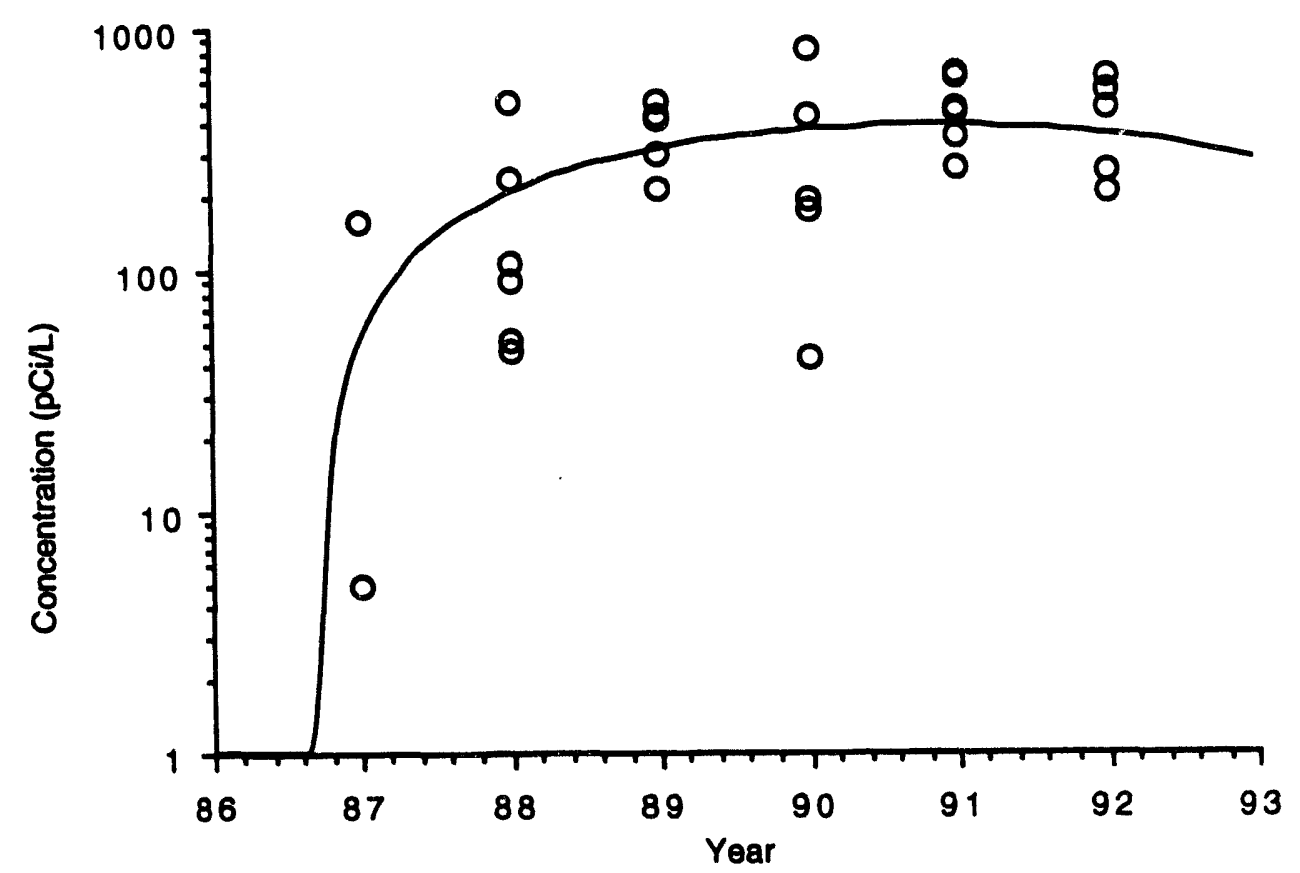

Figure 3.4. Results of Regression Analysis for ${ }^{3} \mathrm{H}$ in Wine from Upwind Locations 
Table 3.5. Tritium in Wine, 1992. Shown are results and the two sigma counting error, in $\mathrm{pCi} / \mathrm{L}$.

\begin{tabular}{|c|c|c|c|c|c|c|c|}
\hline \multicolumn{4}{|c|}{ Washington State Department of Health } & \multicolumn{4}{|c|}{ Surface Environmental Surveillance Project } \\
\hline $\begin{array}{c}\text { Columbia } \\
\text { Basin } \\
\text { Red } \\
\end{array}$ & $\begin{array}{c}\text { Columbia } \\
\text { Basin } \\
\text { White } \\
\end{array}$ & $\begin{array}{c}\text { Yakima } \\
\text { Valley } \\
\text { Red } \\
\end{array}$ & $\begin{array}{l}\text { Yakima } \\
\text { Valloy } \\
\text { White } \\
\end{array}$ & $\begin{array}{c}\text { Columbia } \\
\text { Basin } \\
\text { Red } \\
\end{array}$ & $\begin{array}{c}\text { Columbia } \\
\text { Basin } \\
\text { White } \\
\end{array}$ & $\begin{array}{l}\text { Yakima } \\
\text { Valley } \\
\text { Red } \\
\end{array}$ & $\begin{array}{l}\text { Yakima } \\
\text { Valley } \\
\text { White } \\
\end{array}$ \\
\hline $80 \pm s$ & & & $130 \pm 90$ & & $370 \pm 90$ & $640 \pm 100$ & $250 \pm 90$ \\
\hline $170 \pm 9$ & $90 \pm 90$ & $20 \pm 90$ & $90 \pm 90$ & $380 \pm 90$ & $460 \pm 90$ & $-120 \pm 80$ & $210 \pm 90$ \\
\hline $40 \pm 90$ & $110 \pm 90$ & $140 \pm 90$ & $150 \pm 90$ & $540 \pm 90$ & $190 \pm 80$ & $420 \pm 100$ & $550 \pm 100$ \\
\hline
\end{tabular}

\subsection{Strontium-89}

Strontium-89 is a beta-emitting radionuclide with a half-life of 52.7 days (USDHEW 1970). The principal means of production of this isotope is through activation of stable strontium or through fission. Strontium is a calcium analog in that it will behave in a biological system similar to calcium. In animals, strontium is generally a bone seeker; however, in dairy cattle, strontium also accumulates in milk. In vegetation, strontium is incorporated into enzymes and cellular structures. Strontium-89 was routinely detected in alfalfa.

Because alfalfa was analyzed for ${ }^{89} \mathrm{Sr}$ only in 1982 and 1983, a regression analysis was not performed. The ANOVA performed on the log-transformed data showed no significant difference between the upwind and downwind ${ }^{89} \mathrm{Sr}$ concentrations in alfalfa, $\mathrm{P}$-value $=0.803$; no significant difference for the year effect, $\mathrm{P}$-value $=0.26$; and no significant difference for the upwind/downwind by year effect, P-value $=0.30$. Based on these tests, no Hanford effect could be identified.

\subsection{Strontium-90}

Strontium-90 is a low-energy beta-emitter (maximum energy $546 \mathrm{keV}$ ), with a half-life of 27.7 years (USDHEW 1970). The principal means of production of this isotope is through fission. Strontium- 90 is analyzed by a chemical separation process, which includes treatment with $\mathrm{HNO}_{3}$ (nitric acid) and precipitation with fuming $\mathrm{HNO}_{3}$. The strontium is then scavenged with barium chromate, precipitated as a carbonate, and transferred to a planchet before counting on a gas-flow proportional counter.

Strontium-90 has been identified to be entering the Columbia River through groundwater seeps near the 100-N Area shoreline (Dirkes 1990). The possible pathways of exposure to humans are drinking the river water extracted downstream from the Site, swimming in the river near 100-N Area groundwater seeps, and consuming crops irrigated with Columbia River water withdrawn from the river downstream from the Hanford Site. Global atmospheric fallout is also an exposure pathway. Hanford Site Environmental Reports documented ${ }^{90} \mathrm{Sr}$ as being released to the atmosphere from onsite 
locations (Jaquish and Bryce 1989, 1990; PNL 1987; Price 1986; Price and Carlile 1985; Price et al. 1984; Sula et al. 1983). Figure 3.1 shows estimated curie amounts of ${ }^{90} \mathrm{Sr}$ released to the environment from the Hanford Site between 1982 and 1992.

Contributions of ${ }^{90} \mathrm{Sr}$ to the environment via global fallout are attributable to atmospheric nuclear weapons tests. The last test was in October 1980 by the Peoples Republic of China, and fallout from that test was detected in Pacific Northwest Laboratory air monitors (Jaquish and Bryce 1989, 1990; PNL 1987; Price 1986; Price and Carlile 1985; Price et al. 1984; Sula et al. 1983). In atmospheric weapons tests, fission products are injected into the upper atmospheric levels. Residency times of ${ }^{90} \mathrm{Sr}$ in the atmosphere range from days to several years (Eisenbud 1987) and vary with particle size, wind patterns, and mixing between various layers of the atmosphere. Atmospheric deposition patterns vary with latitude and rain fall patterns (Eisenbud 1987).

Strontium-90 has been routinely detected in alfalfa, milk, vegetables, and wheat.

\subsubsection{Alfalfa}

Alfalfa has been sampled over the past 11 years because it is exposed to atmospheric deposition and in some locations irrigatec. with Columbia River water. Although alfalfa is not directly consumed by humans, the possibility exists that radionuclides found in this media may enter the food chain (alfalfa to cattle to humans) and indirectly lead to a radiological dose to humans.

The ANOVAs performed on the log-transformed data showed no upwind/downwind differences, $P$-value $=0.61$. There was a significant year effect, $P$-value $<0.0001$, and a significant interaction between year and location, $P$-value $=0.092$. Much of the variation may be a result of the different numbers of samples taken and analyzed each year. The location-by-year interaction is shown in Figure 3.5.

A regression analysis was performed on all log-transformed ${ }^{90} \mathrm{Sr}$ data, and the results showed a slight increasing trend in the data during the first half of the review period, followed by a decrease in the last half of the period (see Figure 3.6). The regression line equation of log transformed data was:

$$
Y=-123.8+2.82 * X-0.016 * X^{2} ; P<0.0001
$$

One concentration value from a Moses Lake alfalfa sample (1.57 pCi/g in 1991) was omitted from the calculations as a far-outlier, based on a $Q_{\text {oxp }}$ value of 0.85 , at the $90 \%$ confidence level (Skoog and West 1980). 


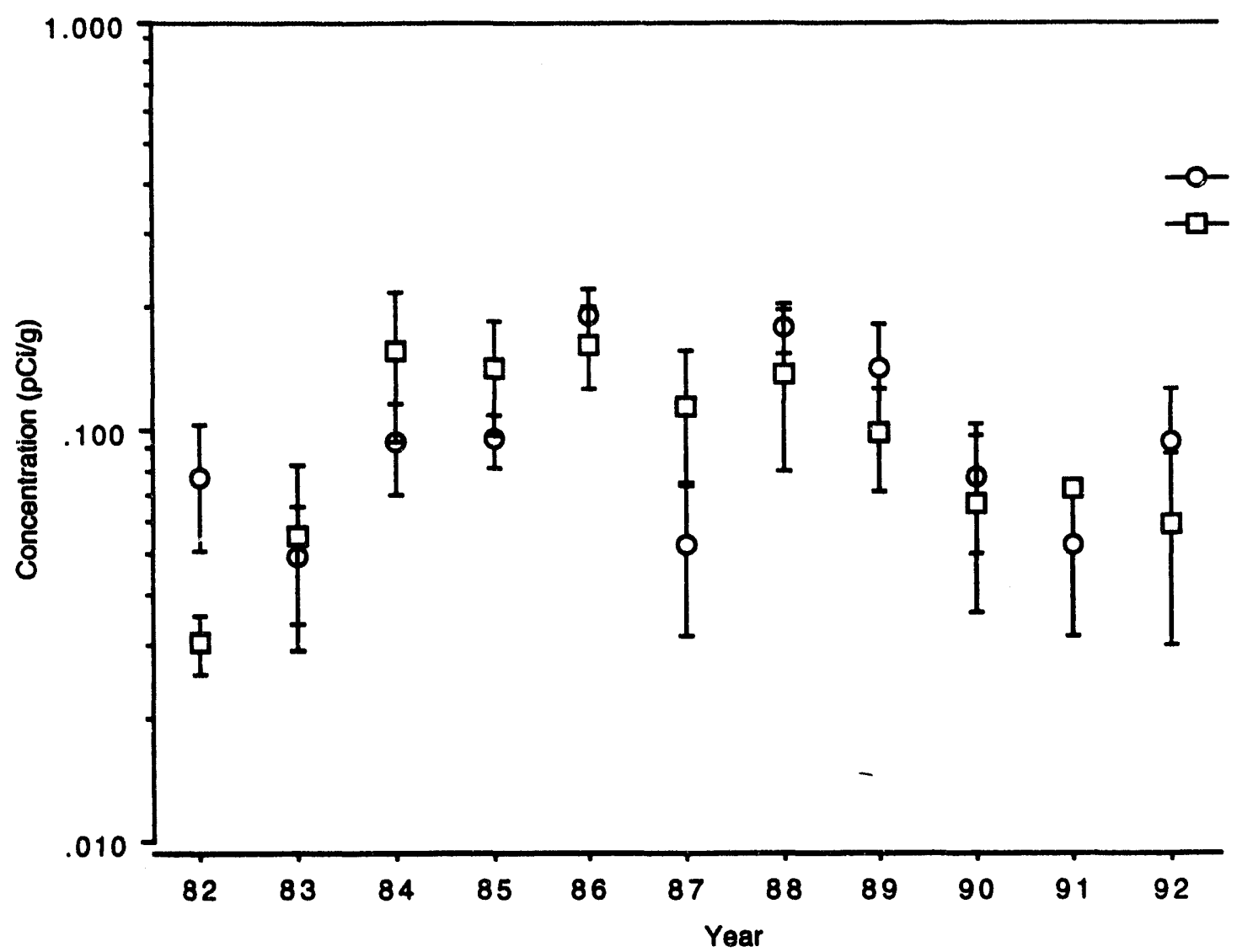

Figure 3.5. Interactions Between Upwind and Downwind Locations and Year for ${ }^{90} \mathrm{Sr}$ in Alfalfa, 1982 Through 1992. Error bars indicate \pm 2 standard errors.

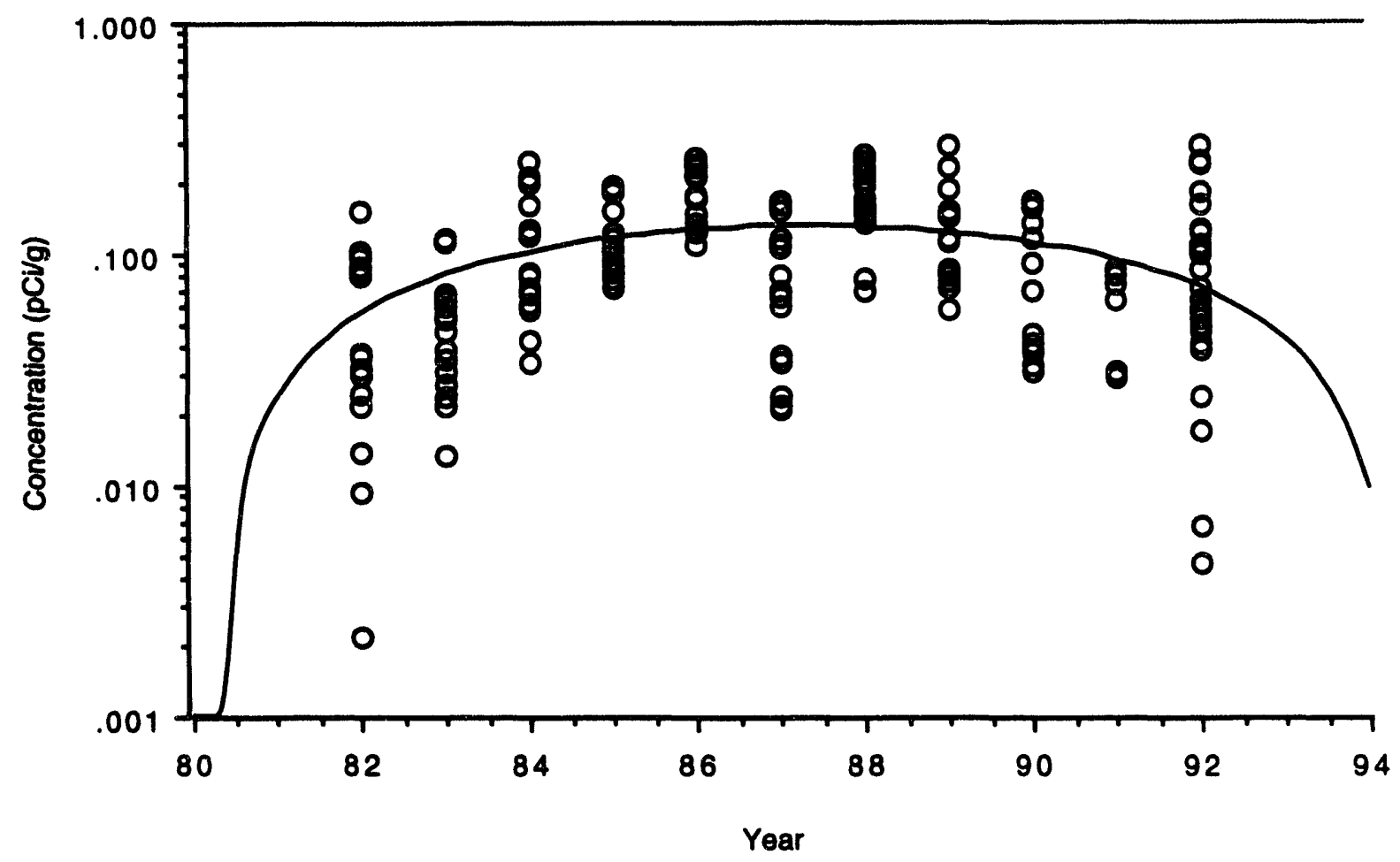

Figure 3.6. Results of Regression Analysis for ${ }^{90} \mathrm{Sr}$ in Alfalfa 
During the past 5 years, samples from locations downstream from Hanford that withdraw irrigation water from the Columbia River tended to have higher ${ }^{90} \mathrm{Sr}$ concentrations than those from background locations that obtain irrigation water from sources other than the Columbia River (Figure 3.7)

(Woodruff et al. 1991, 1992, 1993). A special study on the issue of ${ }^{90} \mathrm{Sr}$ concentration in alfalfa was initiated in 1992 by SESP staff and, although ${ }^{90} \mathrm{Sr}$ concentrations were statistically different based on the source of irrigation water, the Columbia River did not appear to be the source of the ${ }^{90} \mathrm{Sr}$ because Benton City alfalfa samples had the second highest mean ${ }^{90} \mathrm{Sr}$ concentration, even though its irrigation water was not from the Columbia River (Woodruff et al. 1993). The highest mean concentration was from a Horn Rapids location that used Columbia River water as an irrigation source.

\subsubsection{Milk}

Most of the results were below the contractual MDC; however, $94 \%$ of the results were routinely detectable, indicating that the analytical laboratories could detect lower levels than were required.

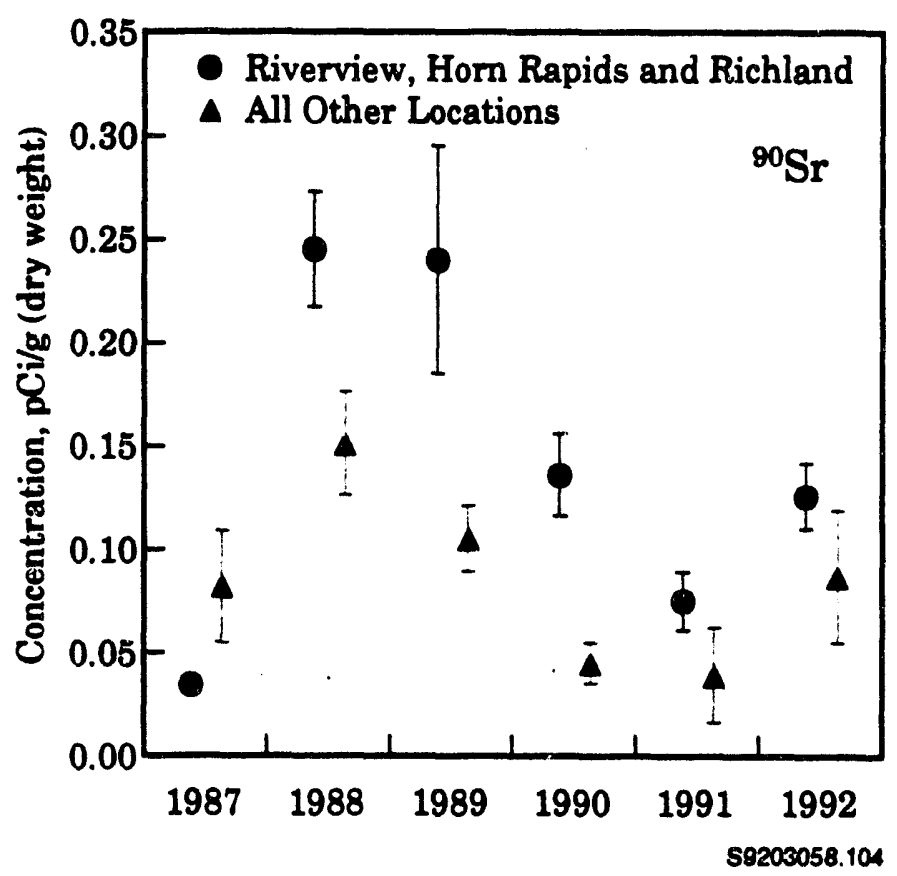

Figure 3.7. Strontium-90 Concentrations ( \pm 2 SEM) in Alfalfa Routinely Collected at Riverview and Richland (Irrigated with Columbia River Water) and All Other Sampling Locations, 1987 Through 1992. As a result of figure scale, some uncertainties are concealed by the point symbol. 
The ANOVAs performed on the log-transformed data indicated that there was no upwind/ downwind effect, but there was a year effect and a location-by-year effect, P-values were 0.29 , $<0.0001$, and 0.0041 , respectively. The year effect may have been driven by different numbers of milk samples analyzed for ${ }^{90}$ Sr each year. Figure 3.8 shows the interaction of upwind and downwind mean ${ }^{90}$ Sr concentrations by year. Based on the ANOVAs, a Hanford effect was not identifiable.

The 11-years' data were pooled across locations, and year was regressed on log concentration. The line of best fit, $\mathbf{R}^{2}=0.183$ (Figure 3.9), was found to be a second power quadratic with the equation:

$$
Y=-22.913+0.562 * X-0.00343 * X^{2} ; P<0.0001
$$

The concentration of ${ }^{90} \mathrm{Sr}$ in milk that would nominally yield a 1-mrem effective dose equivalent to the public is approximately $27 \mathrm{pCi} / \mathrm{L}$. This concentration would produce a radiological dose of $1 \mathrm{mrem}$ if that concentration of ${ }^{90 \mathrm{Sr}}$ in milk was consumed at the rate of $270 \mathrm{~kg} / \mathrm{yr}$, for 1 year. The highest concentration observed in the 11-year period was obtained from the Sunnyside area (an upwind location), with ${ }^{90} \mathrm{Sr}$ concentration of $3.24 \pm 1.82 \mathrm{pCi} / \mathrm{L}$.

\subsubsection{Vegetables}

During the 11-year review period, roughly 440 vegetable samples were collected from various locations off the Hanford Site. Strontium-90 associated with vegetable samples may either be on leaf surfaces from foliar deposition or bound into the plant tissue through root uptake.

The ANOVAs performed on log-transformed data showed no significant difference between upwind and downwind locations, P-value $=0.237$. There were significant year and upwind/ downwind-by-year effects, P-values were $<0.0001$ and 0.0007 , respectively. The year effect difference may be attributable, in part, to the different numbers of samples taken each year during the review period. Figure 3.10 shows the interaction of the upwind/downwind means by year.

Based on these results, no difference between upwind and downwind locations can be demonstrated; therefore, no Hanford effect is noted.

Regression analysis on the pooled log-transformed data, Figure 3.11, showed a slight decrease in ${ }^{90} \mathrm{Sr}$ concentrations over the review period. An $\mathrm{R}^{2}$ of 0.026 , however, indicated very little (no) trend in $90 \mathrm{Sr}$ concentration in vegetables. The equation of the regression line was:

$$
Y=-3.573+0.061 * X-0.000522 * X^{2} ; P=0.0045
$$

The concentration of ${ }^{90} \mathrm{Sr}$ that would yield a nominal 1-mrem effective dose equivalent to the public is approximately $0.27 \mathrm{pCi} / \mathrm{g}$ for leafy vegetables and $0.025 \mathrm{pCi} / \mathrm{g}$ for fruits and other vegetables. These concentrations of ${ }^{90} \mathrm{Sr}$ in vegetables would produce a 1 -mrem effective dose equivalent if leafy vegetables were consumed at a rate of $30 \mathrm{~kg} / \mathrm{yr}$, or other nonleafy vegetables were consumed at the rate of $220 \mathrm{~kg} / \mathrm{yr}$, for 1 full year. 


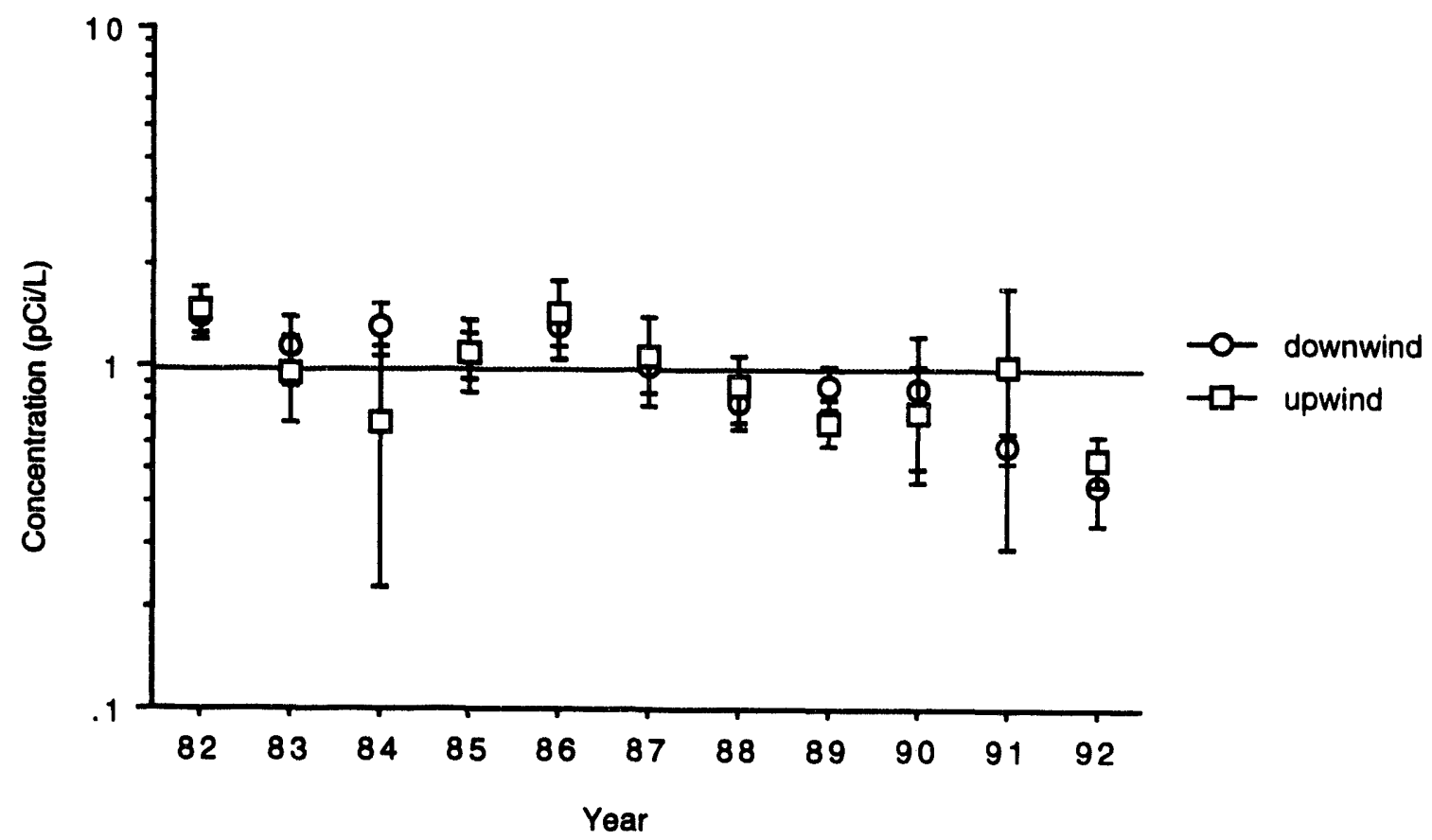

Figure 3.8. Interactions Between Upwind and Downwind Locations and Year for ${ }^{90} \mathrm{Sr}$ in Milk, 1982 Through 1992. Error bars indicate \pm 2 standard t.rors.

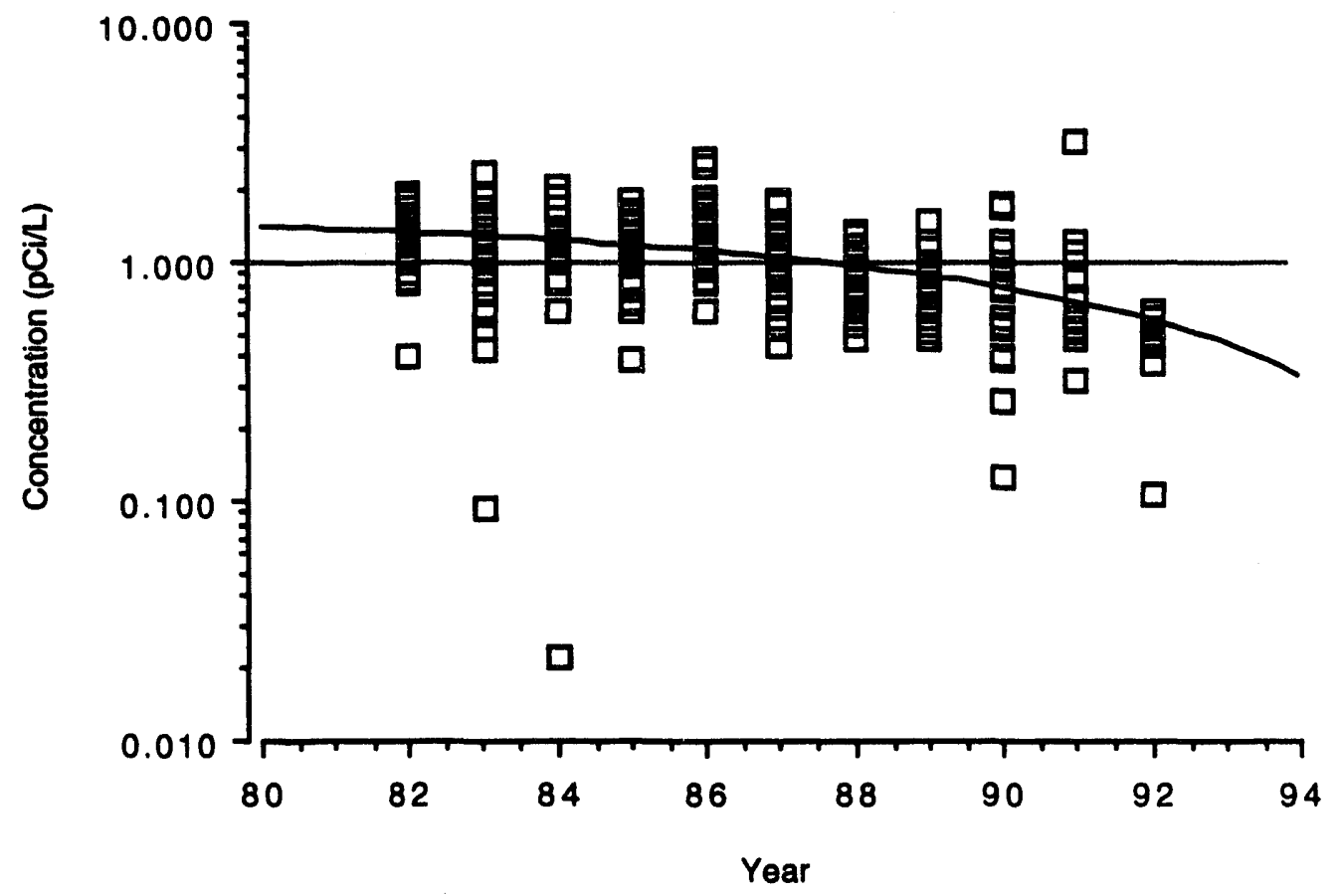

Figure 3.9. Results of Regression Analysis for ${ }^{90} \mathrm{Sr}$ in Milk 


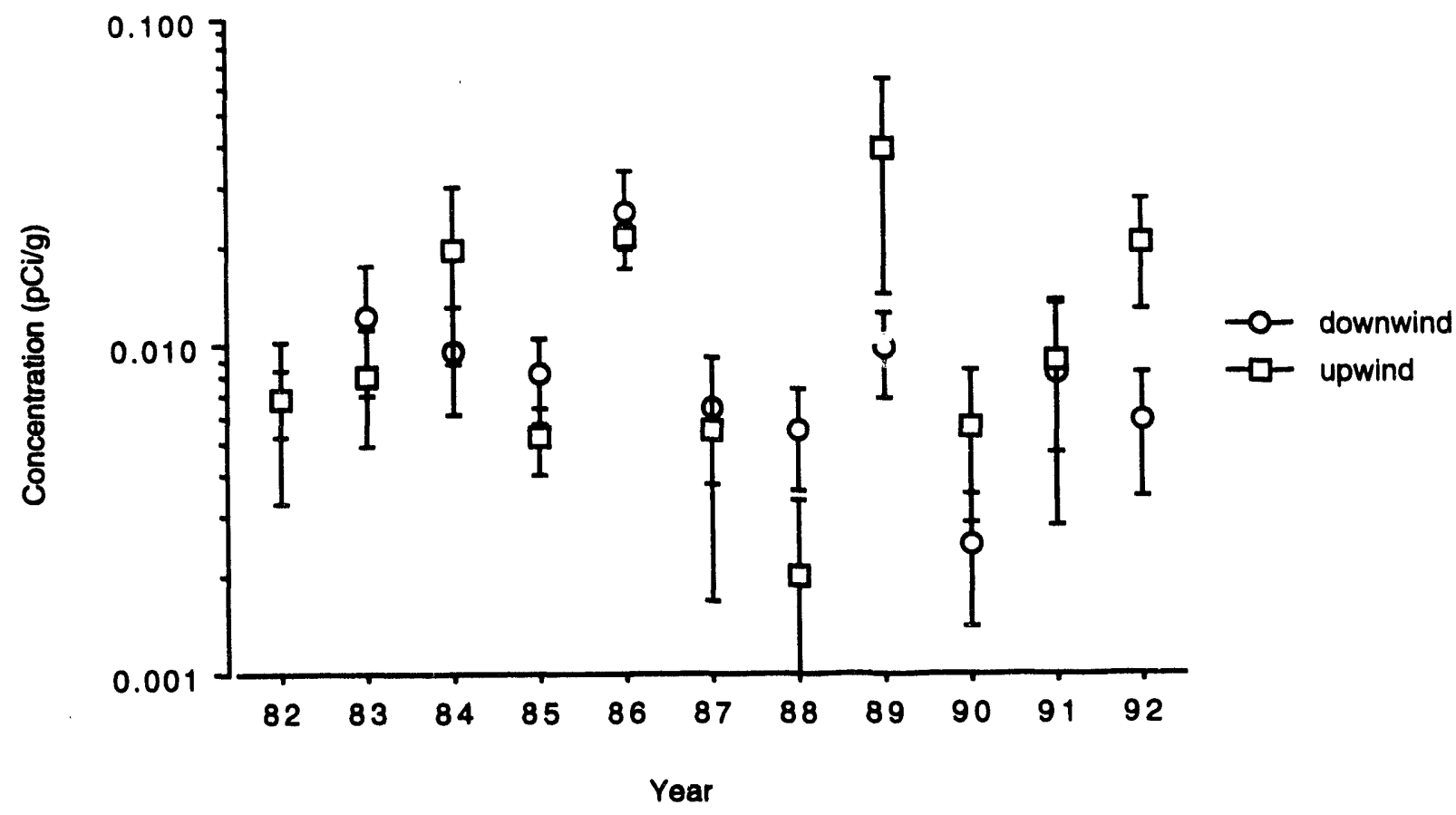

Figure 3.10. Interactions Between Upwind and Downwind Locations and Year for ${ }^{90} \mathrm{Sr}$ in Vegetables, 1982 Through 1992. Error bars indicate \pm 2 standard errors.

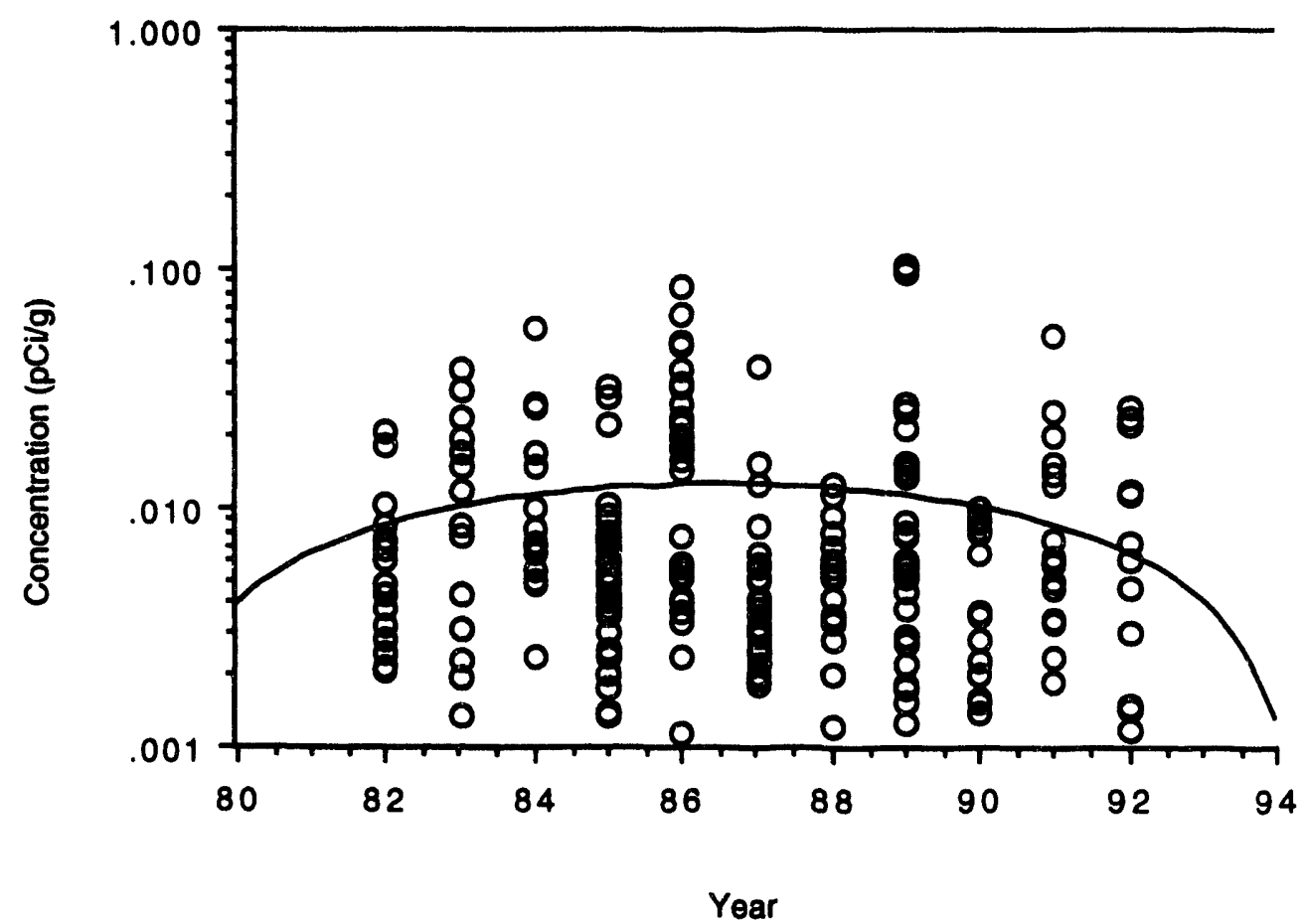

Figure 3.11. Results of Regression Analysis for ${ }^{90} \mathrm{Sr}$ in Vegetables 


\subsubsection{Wheat}

Wheat has been sampled over the past 11 years because it is exposed to atmospheric deposition and also possibly irrigated with Columbia River water. The wheat may be consumed by farmers or sold commercially for human consumption.

The ANOVAs indicated no significant difference between upwind and downwind locations, but there were significant differences between years and the upwind/downwind-by-year interaction, P-values were $0.53,<0.0001$, and 0.009 , respectively. The variability between years may be in part a result of different numbers of samples taken each year. Data for 1992 were disregarded for the ANOVAs, because all three samples submitted for analysis in 1992 were from downwind locations. Without corresponding upwind data for 1992, no valid ANOVA could be performed on upwind/ downwind locations (the degrees of freedom went to zero when 1992 data were included). The upwind/downwind-by-year interaction is shown in Figure 3.12.

Because there was no significant difference between locations, they were pooled for the regression analysis. The line of best fit was a parabola with the equation:

$$
Y=-184.307+4.252 * X-0.025 * X^{2} ; P<0.0001
$$

with an $\mathbf{R}^{2}=0.363$ (Figure 3.13). Based on the results of the ANOVAs, no Hanford effect can be seen. A nominal concentration of $0.1 \mathrm{pCi} / \mathrm{g}$ would produce a radiological dose of $1 \mathrm{mrem}$ if that concentration of ${ }^{90} \mathrm{Sr}$ in cereals and grains was consumed at the rate of $80 \mathrm{~kg} / \mathrm{yr}$ (wet), for approximately 1 year.

\section{4 lodine-129}

lodine-129 is a fission product with a half-life of 17 billion years (USDHEW 1970). The maximum energy of the beta particle emitted by this isotope is $150 \mathrm{keV}$. The major source of ${ }^{129} \mathrm{I}$ on the Hanford Site was the PUREX Facility located in the 200 Areas. PUREX Plant emissions are summarized in Hanford Site environmental monitoring annual reports (e.g., Woodruff et al. 1991) and by Patton and Cooper (1993). The pathway of ${ }^{129} \mathrm{I}$ from Site emissions to humans is atmospheric release $\rightarrow$ deposition onto plant surfaces $\rightarrow$ ingestion by cattle $\rightarrow$ transfer to milk $\rightarrow$ ingestion of milk by humans. Iodine-129 in milk has a mass spectral analysis detection limit of $0.00006 \mathrm{aCi} / \mathrm{L}$. It was routinely detected in milk.

The ANOVAs performed on the log-transformed data indicated a significant difference between the upwind and downwind locations and between sampling years; P-values were $<0.0001$ for both analyses. There was no significant interaction between year and upwind/downwind location, P-value $=0.93$ (Figure 3.14). 


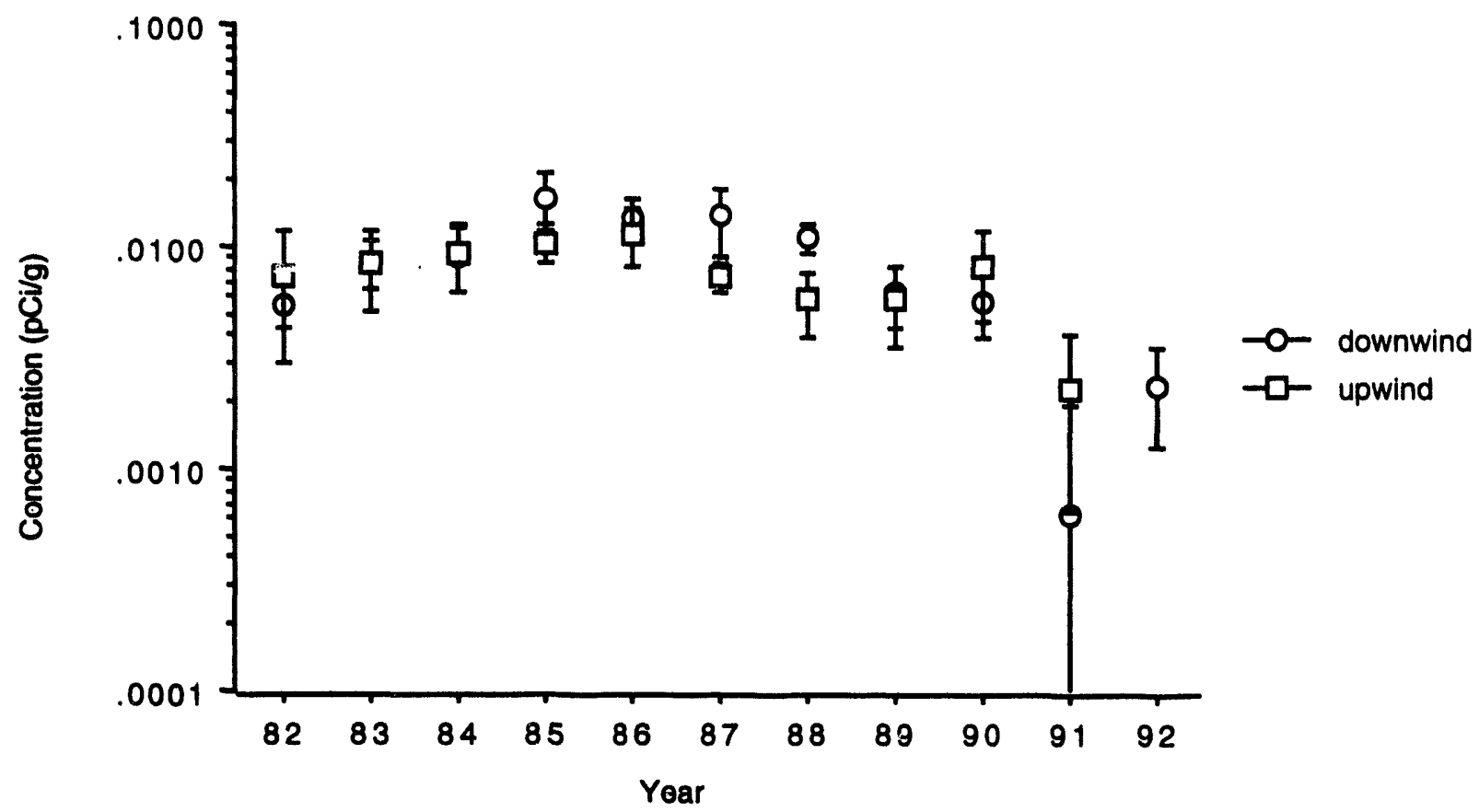

Figure 3.12. Interactions Between Upwind and Downwind Locations and Year for ${ }^{90} \mathrm{Sr}$ in Wheat, 1982 Through 1992. Error bars indicate \pm standard errors.

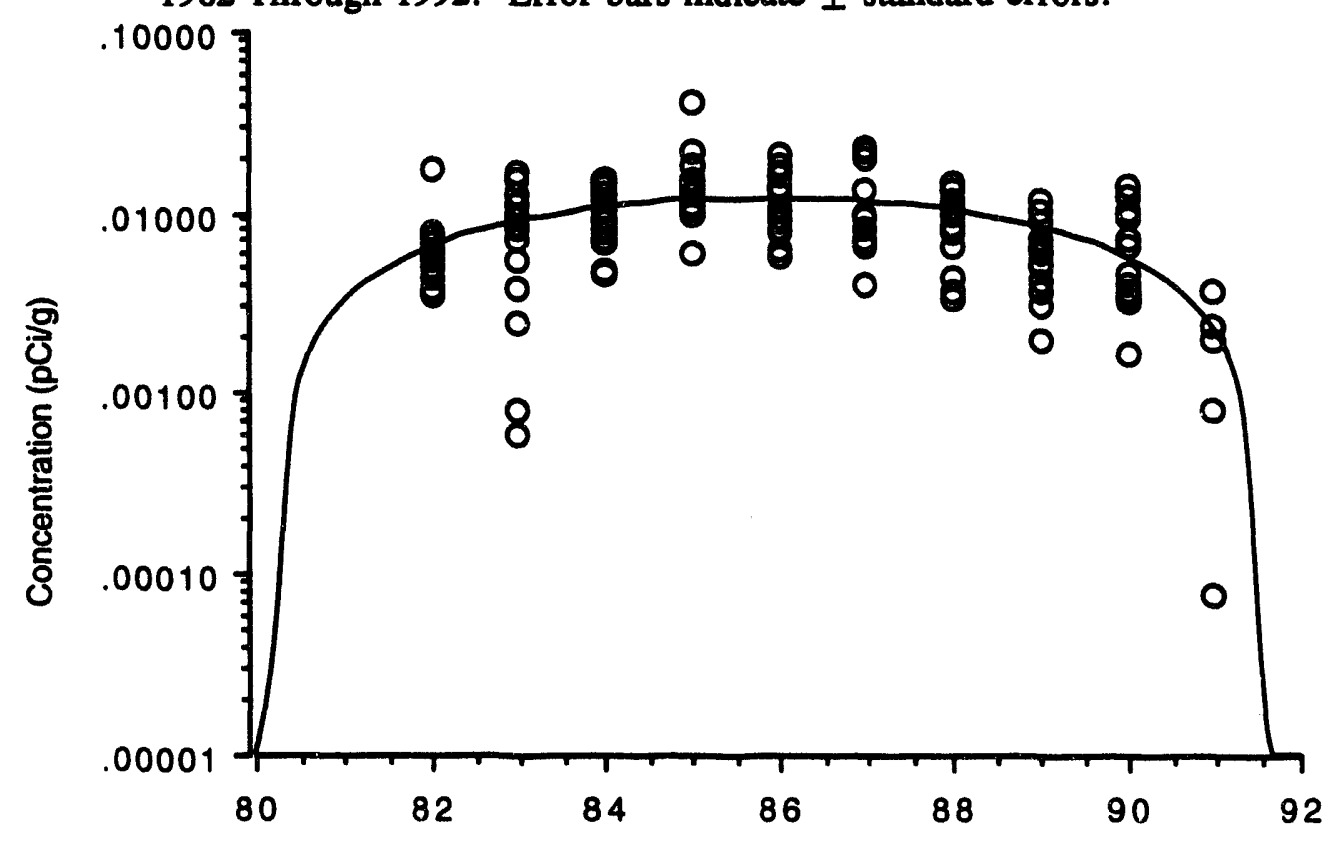

Year

Figure 3.13. Results of Regression Analysis for ${ }^{90} \mathrm{Sr}$ in Wheat 


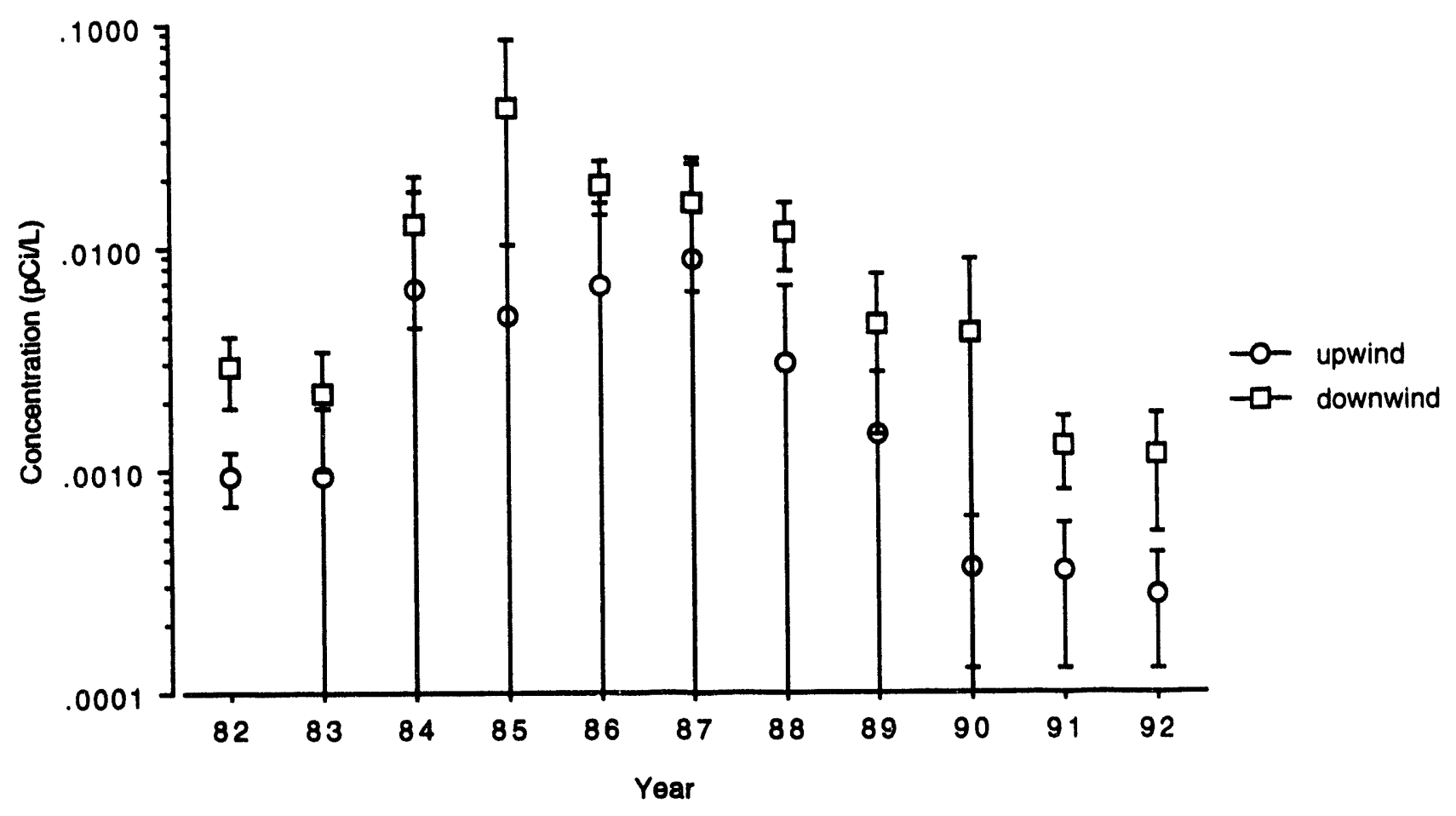

Figure 3.14. Interactions Between Upwind and Downwind Locations and Year for ${ }^{129} I$ in Milk, 1982 Through 1992. Error bars indicate \pm 2 standard errors.

Because the ANOVAs indicated that the upwind samples were different from the downwind samples, the two data sets were regressed separately. Both sets were best fit by parabolic functions. The regression line that best fit the upwind data, Figure 3.15, was:

$$
Y=-234.847+5.406 * X-0.031 * X^{2} ; R^{2}=0.285 ; P=0.002
$$

The regression line that best fit the downwind data, Figure 3.16, was:

$$
Y=-338.253+7.788 * X-0.045 * X^{2} ; R^{2}=0.505 ; P<0.0001
$$

Mean ${ }^{129} \mathrm{I}$ concentrations in milk \pm 2 standard errors of the mean are shown in Figure 3.14. A noticeable increase in sample concentrations from downwind locations from 1983 to 1985 corresponds to the restart of the PUREX Plant (Patton and Cooper 1993). The upwind locations also show an effect from the restart. The decrease from 1985 through 1992 corresponds to the decrease in reactor fuel processing at the PUREX Plant and the completion of plutonium processing in March 1990 (Patton and Cooper 1993). The PUREX plant did not operate in 1991 and 1992.

The concentration of ${ }^{129} \mathrm{I}$ in dairy products that would yield a nominal 1 -mrem effective dose equivalent to the public is approximately $13 \mathrm{pCi} / \mathrm{L}$. Consumption of milk with this concentration for a year at a rate of $270 \mathrm{~L} / \mathrm{y}$ would yield a radiological dose of $1 \mathrm{mrem}$ effective dose equivalent. A concentration as high as $13 \mathrm{pCi} / \mathrm{L}$ was not measured during the review period. 


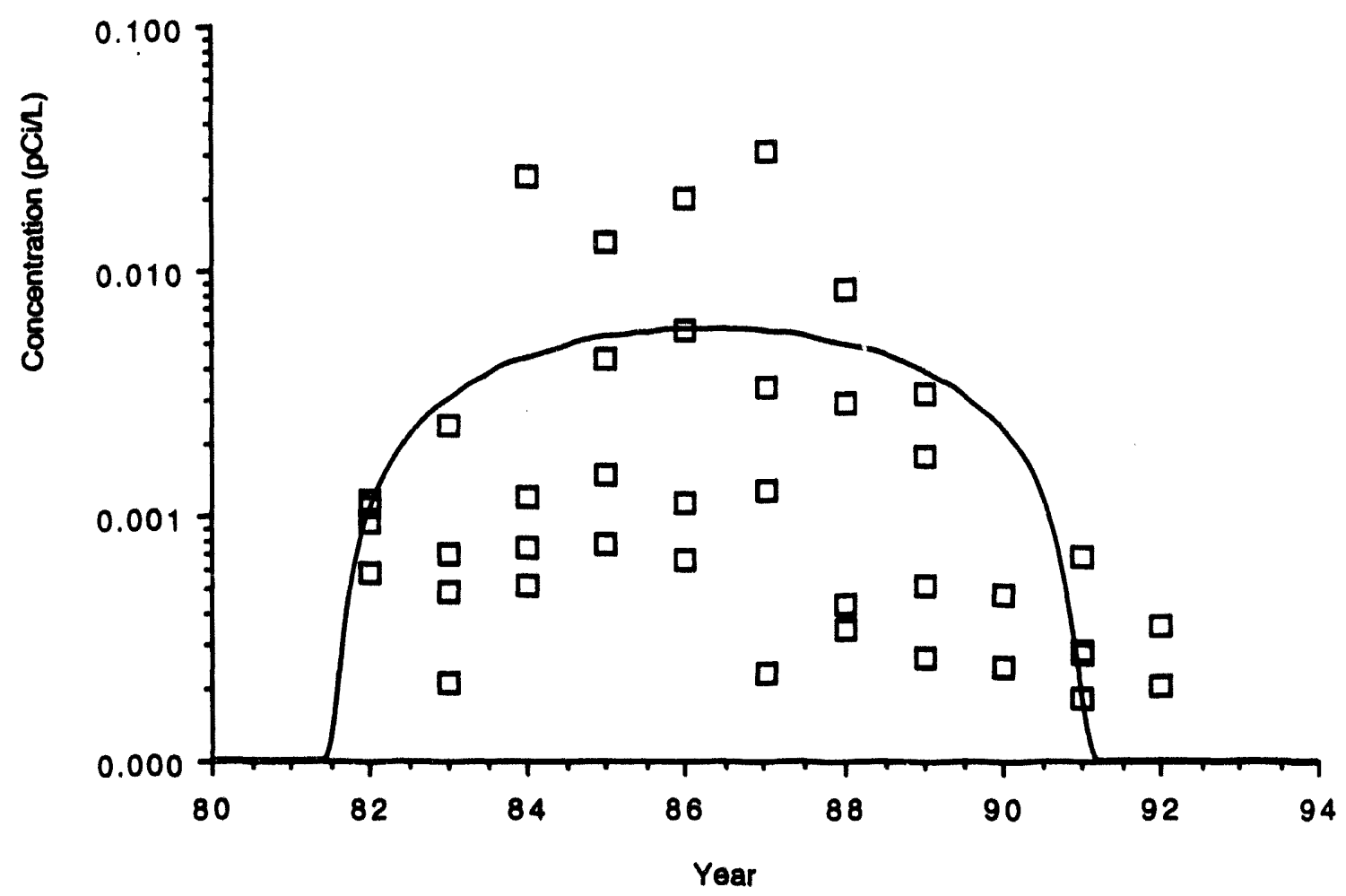

Figure 3.15. Results of Regression Analysis for Upwind Locations for ${ }^{129} 1$ in Milk

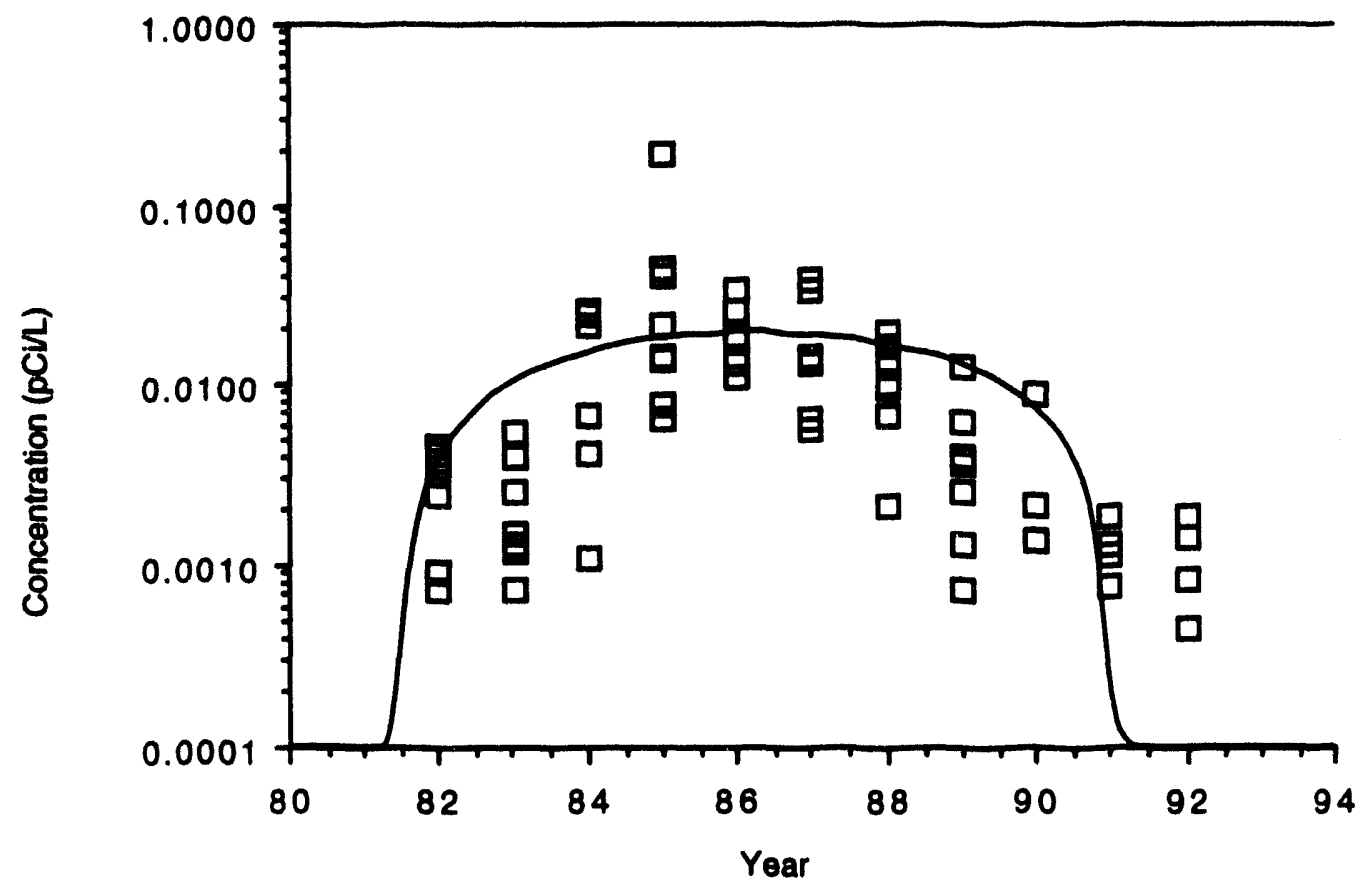

Figure 3.16. Results of Regression Analysis for Downwind Locations for ${ }^{129} 1$ in Milk 


\section{5 lodine-131}

lodine-131 is a beta emitter with a maximum energy of $806 \mathrm{keV}$ and a half-life of 8.05 days (USDHEW 1970). Although ${ }^{131} I$ in milk was rarely detected (42 detectable measurements of 907 total), this media/radionuclide combination is discussed because ${ }^{131}$ I was detected following the Chernobyl incident. In the 11 years of data that were graphed (Figure 3.17), only 1986 showed measurable concentrations of ${ }^{131} 1$. The peak observed in 1986 is related to global fallout from the accident at Chernobyl in May 1986 (Eberhardt et al. 1989; Poston 1991; Price 1987). No trends were noticed while reviewing the data.

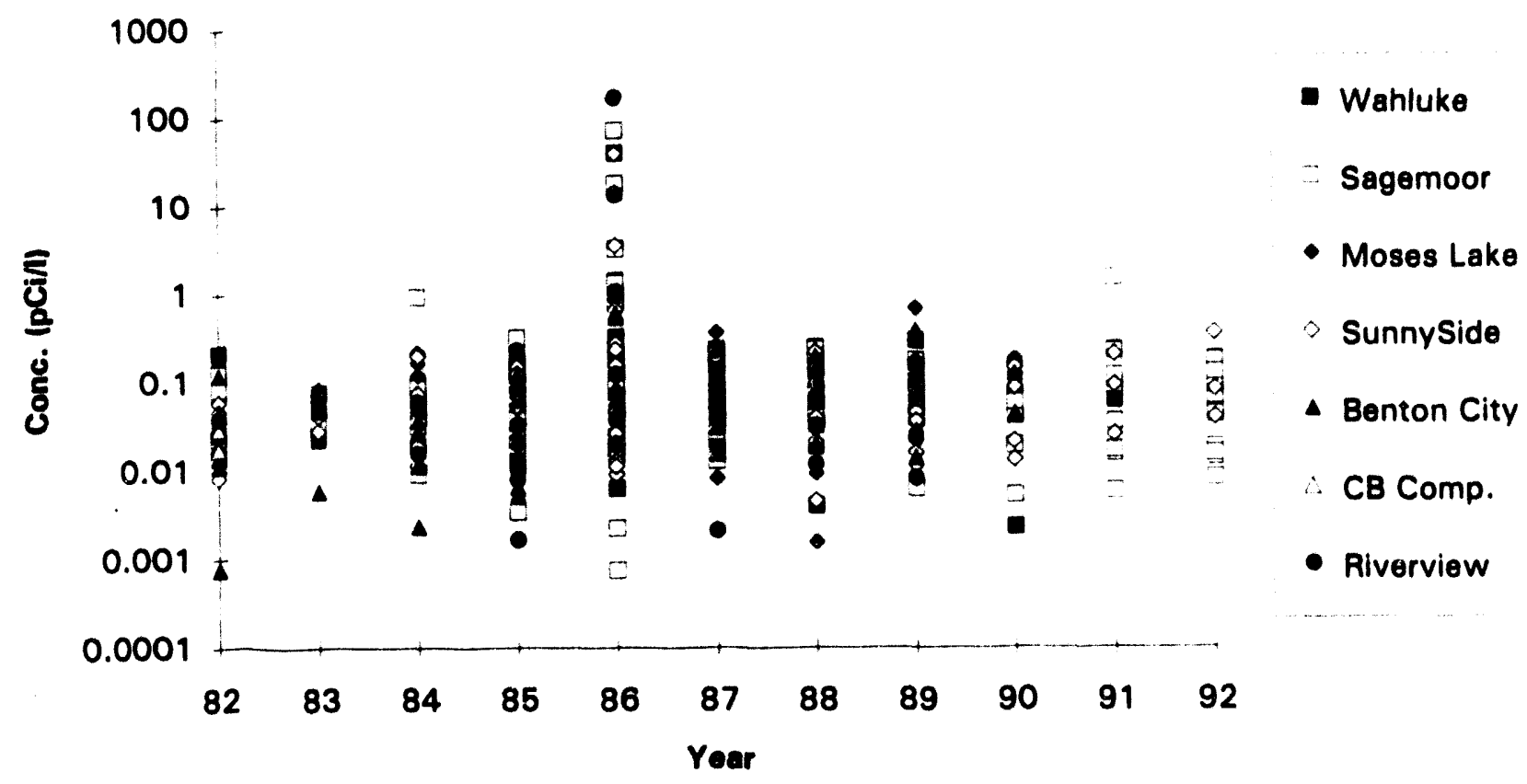

Figure 3.17. Iodine-131 Concentrations in Milk, 1982 Through 1992 


\subsection{Conclusions}

A review of monitoring data for agricultural products collected from 1982 through 1992 near the Hanford Site was conducted to determine trends in radionuclide concentrations and from year to year. Media reviewed included milk, chicken, eggs, beef, vegetables, fruit, wine, wheat, and alfalfa. The review indicated the following:

- Radionuclide concentrations in these media remained relatively low when compared to concentrations that would result in a 1 -mrem effective dose equivalent to an individual.

- Out of numerous radionuclide/media combinations, only seven combinations were routinely detected.

- Hanford effects (i.e., greater downwind vs. upwind concentrations) could not be identified for ${ }^{3} \mathrm{H}$ in wine, ${ }^{89} \mathrm{Sr}$ in alfalfa, or ${ }^{90} \mathrm{Sr}$ in alfalfa, milk, vegetables, and wheat.

- Strontium-90 concentrations increased from 1982 to 1986 , then decreased gradually for the remainder of the review period.

- Iodine-129 concentrations in milk appear to follow a trend similar to those of ${ }^{90} \mathrm{Sr}$ and may be correlated with processing of irradiated reactor fuel at the PUREX Plant. Both upwind and downwind ${ }^{129} \mathrm{I}$ concentrations in milk follow the same time trend as Hanford air emissions (Figure 4.1), but differ in magnitude. This indicates that Hanford operations affect both upwind and downwind locations. Patton and Cooper (1993) showed a strong correlation between annual ${ }^{129}$ I stack emissions and annual average air concentrations in Yakima.

- Radionuclide concentrations in other media are decreasing or are not detectable with state of the art detection techniques. 


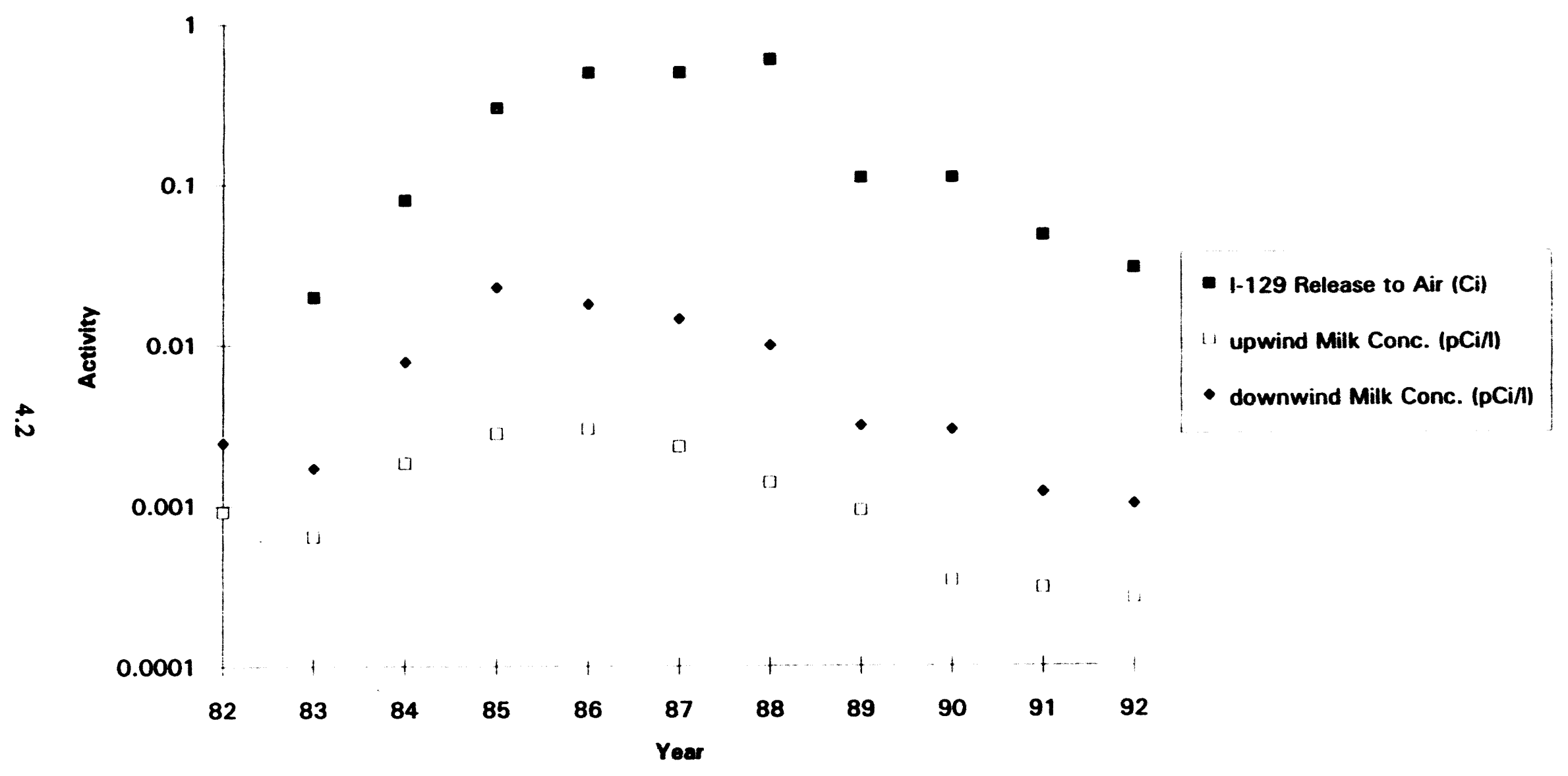

Figure 4.1. Annual Hanford ${ }^{129}$ I Air Emissions and Annual Average Milk Concentrations, 1982 Through 1992 


\subsection{References}

Denham, D. H., R. L. Dirkes, R. W. Hanf, T. M. Poston, M. E. Thiede, and R. K. Woodruff. 1993. Phase I Summaries of Radionuclide Concentration Data for Vegetation. River Water. Drinking Water. and Eish. PNWD-2145 HEDR, Pacific Northwest Laboratory, Richland, Washington.

Dirkes, R. L. 1990. Hanford Riverbank Springs Characterization Report. PNL-7500, Pacific Northwest Laboratory, Richland, Washington.

Eberhardt, L. E., K. R. Price, L. L. Cadwell, and D. W. Carlile. 1989. Trends in Radionuclide Concentrations for Selected Wildlife and Food Products Near the Hanford Site From 1971

Through 1988. PNL-6992, Pacific Northwest Laboratory, Richland, Washington.

Eisenbud, M. 1987. Environmental Radioactivity. 3rd Edition, Academic Press, Orlando, Florida.

Friedlander, G., J. W. Kennedy, and J. M. Miller. 1964. Nuclear and Radiochemistry. 2nd Edition, John Wiley \& Sons, Inc., New York.

Jaquish, R. E., and R. W. Bryce. 1989. Hanford Site Environmental Repert for Calendar Year 1988. PNL-6825, Pacific Northwest Laboratory, Richland, Washington.

Jaquish, R. E., and R. W. Bryce. 1990. Hanford Site Environmental Repert for Calendar Year 1989. PNL-7346, Pacific Northwest Laboratory, Richland, Washington.

NCRP (National Council on Radiation Protection and Measurements). 1976. Environmental Radiation Measurements. NCRP Report No. 50, National Council on Radiation Protection and Measurements, Washington, D.C.

NCRP (National Council on Radiation Protection and Measurements). 1978. A Handbook of Radioactivity Measurements Procedures. NCRP Report No. 58, National Council on Radiation Protection and Measurements, Washington, D.C.

Patton, G. W., and A. T. Cooper. 1993. Air Pathway Effects of Nuclear Materials Production at the Hanford Site, 1983 to 1992. PNL-8830, Pacific Northwest Laboratory, Richland, Washington.

PNL (Pacific Northwest Laboratory). 1987. Environmental Monitorine at Hanford for 1986. PNL-6120, Pacific Northwest Laboratory, Richland, Washington.

Poston, T. M. 1991. "Food and Farm Product Surveillance." In Hanford Site Environmental Report for Calendar Year 1990, pp 97-103. PNL-7930, Pacific Northwest Laboratory, Richland, Washington. 
Price, K. R. 1986. Environmental Monitoring at Hanford for 1985. PNL-5817, Pacific Northwest Laboratory, Richland, Washington.

Price, K. R. 1987. "Food and Farm Product Monitoring." In Environmental Monitoring at Hanford for 1986, pp 3.38-3.41. PNL-6120, Pacific Northwest Laboratory, Richland, Washington.

Price, K. R., and J.M.V. Carlile. 1985. Environmental Monitoring at Hanford for 1984. PNL-5407, Pacific Northwest Laboratory, Richland, Washington.

Price, K. R., J.M.V. Carlile, R. L. Dirkes, and M. S. Trevathan. 1984. Environmental Surveillance at Hanford for CY-1983. PNL-5038, Pacific Northwest Laboratory, Richland, Washington.

Skoog, D. A., and D. M. West. 1980. Analytical Chemistry. 3rd Edition, Saunders College, Philadelphia, Pennsylvania.

Sula, M. J., J.M.V. Carlile, K. R. Price, and W. D. McCormack. 1983. Environmental Surveillance at Hanford for CY-1982. PNL-4657, Pacific Northwest Laboratory, Richland, Washington.

Supply System (Washington Public Power Supply System). ca. 1991. 1990 50-Mile Land Use Census. Washington Public Power Supply System, Radiological Environmental Monitoring Program, Richland, Washington.

Till, J. E., and H. R. Meyer. 1983. Radiological Assessment. A Textbook on Environmental Dose Analysis. U.S. Government Printing Office, Washington, D.C.

USDHEW (U.S. Department of Health, Education, and Welfare). 1970. Radiological Health Handbook. Bureau of Radiological Health, Rockville, Maryland.

Woodruff, R. K., R. W. Hanf, M. G. Hefty, and R. E. Lundgren, eds. 1991. Hanford Site Environmental Report for Calendar Year 1990. PNL-7930, Pacific Northwest Laboratory, Richland, Washington.

Woodruff, R. K., R. W. Hanf, and R. E. Lundgren, eds. 1992. Hanford Site Environmental Report for Calendar Year 1991. PNL-8148, Pacific Northwest Laboratory, Richland, Washington.

Woodruff, R. K., R. W. Hanf, and R. E. Lundgren, eds. 1993. Hanford Site Environmental Report for Calendar Year 1992. PNL-8682, Pacific Northwest Laboratory, Richland, Washington. 


\section{Distribution}

No of

Copies

\section{OFPSTE}

12 DOE/Office of Scientific and Technical Information

\section{ONSTME}

DOE Richland Operations Ofrice

J. B. Hall

18 Pacific Northwest Laboratory

E. J. Antonio (5)

K6-61

R. E. Lundgren

K6-62

T. M. Poston

$\mathrm{K} 6-61$

H. E. Westerdahl

K6-60

R. K. Woodruff

K6-61

Publishing Coordination

SESP Historical Files/

R. K. Woodruff (2)

K6-61

Technical Report Files (5)

\section{Routing}

R. M. Ecker

M. J. Graham

P. M. Irving

C. S. Sloane

P. C. Hays (last)

Distr.1 

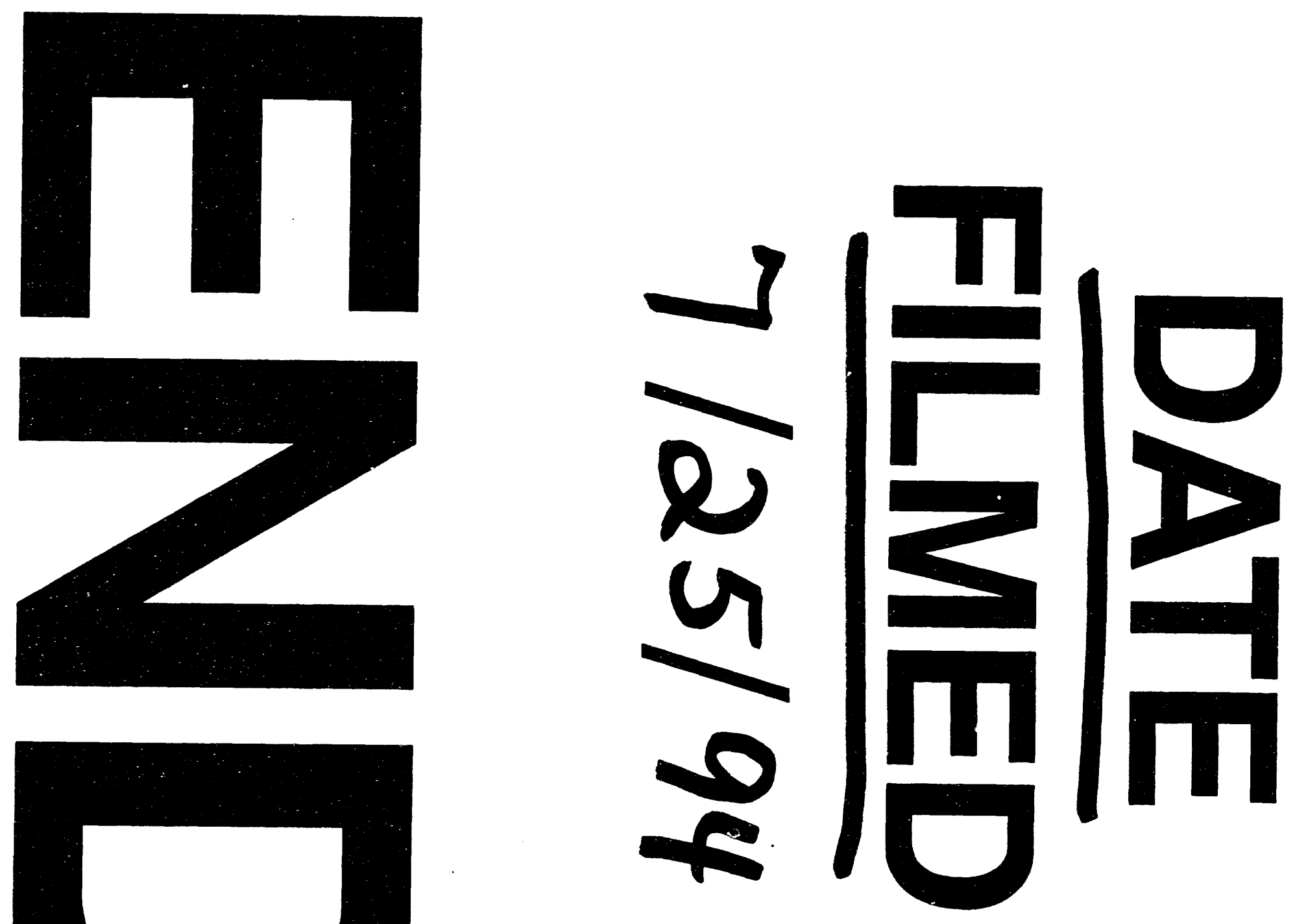
